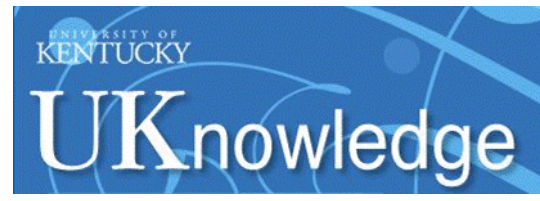

University of Kentucky

UKnowledge

$1-2019$

\title{
Precedent, Three-Judge District Courts, and the Law of Democracy
}

Joshua A. Douglas

University of Kentucky, joshuadouglas@uky.edu

Follow this and additional works at: https://uknowledge.uky.edu/law_facpub

Part of the Election Law Commons

Right click to open a feedback form in a new tab to let us know how this document benefits you.

\section{Repository Citation}

Douglas, Joshua A., "Precedent, Three-Judge District Courts, and the Law of Democracy" (2019). Law Faculty Scholarly Articles. 637.

https://uknowledge.uky.edu/law_facpub/637

This Article is brought to you for free and open access by the Law Faculty Publications at UKnowledge. It has been accepted for inclusion in Law Faculty Scholarly Articles by an authorized administrator of UKnowledge. For more information, please contact UKnowledge@lsv.uky.edu. 


\section{Precedent, Three-Judge District Courts, and the Law of Democracy}

Notes/Citation Information

Joshua A. Douglas, Precedent, Three-Judge District Courts, and the Law of Democracy, 107 Geo. L.J. 413 (2019). 


\title{
Precedent, Three-Judge District Courts, and the Law of Democracy
}

\author{
Joshua A. Douglas* \& Michael E. Solimine**
}

As recent partisan gerrymandering cases have shown, three-judge district courts play a unique and important role in how the federal judiciary considers significant election law disputes. Yet two somewhat quirky procedural questions involving these courts remain unresolved: first, is a Supreme Court ruling to summarily affirm a three-judge district court's decision precedential on all future courts? That is, why should a one-line order from the Supreme Court, without explanation, formally bind all future courts on the issue, especially when it is unclear what aspect of the lower court's decision was correct? Second, must a three-judge district court follow, as mandatory authority, circuit precedent in the circuit in which it sits, even though an appeal from the ruling of a three-judge district court will skip the court of appeals and go directly to the U.S. Supreme Court?

This Article tackles these problems and provides clear-cut answers, which will ultimately improve judicial decisionmaking for some of the most important cases that the federal judiciary hears given their effect on democracy. On the first question, we find that summary decisions of the U.S. Supreme Court are entitled to zero or very little precedential value, and therefore that the Justices need not feel obliged to hear these cases in full if they want the issue to percolate in the lower courts first. Yet there should be a presumption in favor of the Court providing legal guidance on the issue, meaning that most of the time it should set the case for oral argument and provide a full written opinion. On the second question, we conclude that circuit precedent is not formally binding on threejudge district courts, although of course in many cases it will be highly persuasive.

Procedural questions stemming from three-judge district courts impact their substantive rulings, which mostly involve redistricting and campaign finance. Resolving these two questions on the procedures involving three-judge district courts will help to ensure that these special

\footnotetext{
* Thomas P. Lewis Professor of Law, University of Kentucky College of Law. (C) 2018, Joshua A. Douglas and Michael E. Solimine.

** Donald P. Klekamp Professor of Law, University of Cincinnati College of Law. We benefited greatly from what we learned after presenting this Article at faculty workshops at the University of Cincinnati College of Law and the University of Kentucky College of Law. Thanks also to Michael Dimino, Rick Hasen, Michael Morley, Mike Pitts, and Richard Re for insightful comments. Chris Jacovitch and Grant Sharp of the University of Kentucky College of Law provided invaluable research assistance.
} 
courts operate as Congress intended, ultimately improving our electoral system.

\section{TABLE OF CONTENTS}

INTRODUCTION .

I. History and Operation of Three-Judge District Courts . . . . . . . .

A. BRIEF HISTORY OF THREE-JUDGE DISTRICT COURTS . . . . . . . . . 419

B. MECHANICS OF THREE-JUDGE DISTRICT COURTS . . . . . . . . . .

II. The Precedential Weight of the Supreme Court's Summary Dispositions of ApPeals from Three-Judge District Courts . . . . . .

A. CURRENT JURISPRUDENTIAL STATUS OF SUMMARY DISPOSITIONS FROM THE SUPREME COURT $\ldots \ldots \ldots \ldots \ldots \ldots \ldots \ldots$

B. WHY THE SUPREME COURT SHOULD CHANGE ITS APPROACH TO SUMMARY AFFIRMANCES OF THREE-JUDGE DISTRICT COURTS . . . . . .

C. REFORMING THE COURT'S SUMMARY DISPOSITION PRACTICE ......

D. REFORMING THE COURT'S NARROW CANON OF CONSTRUCTION OF THE THREE-JUDGE COURT ACT $\ldots \ldots \ldots \ldots \ldots \ldots \ldots \ldots \ldots$

III. Precedent That Binds Three-Judge District Courts . . . . . . . . . . 438

A. CURRENT VIEWS ON WHETHER CIRCUIT PRECEDENT SHOULD BIND THREE-JUDGE DISTRICT COURTS . . . . . . . . . . . . . . . . 438

B. SIGNIFICANCE OF DETERMINING WHICH PRECEDENT APPLIES ......

C. THREE-JUDGE DISTRICT COURTS AND THE HIERARCHY OF FEDERAL COURTS . . . . . . . . . . . . . . . . . . . . . . . . . .

D. PRUDENTIAL CONSIDERATIONS FOR DETERMINING THE PRECEDENTIAL WEIGHT OF CIRCUIT LAW ON THREE-JUDGE DISTRICT

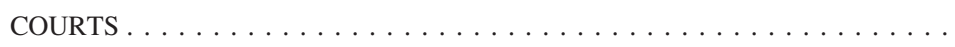

E. ONLY SUPREME COURT PRECEDENT BINDS THREE-JUDGE DISTRICT COURTS, BUT CIRCUIT LAW IS PERSUASIVE

Conclusion

\section{INTRODUCTION}

During the 2017 Supreme Court Term, the Justices heard two cases on partisan gerrymandering that most of them probably would have preferred to avoid. The 
cases, Gill v. Whitford ${ }^{1}$ and Benisek v. Lamone, ${ }^{2}$ included complex facts, politically charged discourse, and little clarity - the kinds of disputes the Court often would refuse to hear, at least until lower courts had more fully vetted the legal issues. ${ }^{3}$ Both cases involved challenges to egregious partisan gerrymanders: Gill attacked the entire Wisconsin state legislative map, which Republicans had gerrymandered to favor their side $;^{4}$ Benisek presented a challenge to one congressional district in Maryland's map, which Democrats had gerrymandered to remove Republican control of that district. ${ }^{5}$ The cases presented a significant clash between law and politics, and any decision on the merits would likely make the Court look political, something it purportedly abhors.

During the oral argument in Gill, Chief Justice Roberts lamented that if the Court invalidated Wisconsin's map as an unconstitutional partisan gerrymander, "there will naturally be a lot of these claims raised around the country. . . And every one of them will come here for a decision on the merits." According to Chief Justice Roberts, this fact would lead the Court to look too political and harm its institutional legitimacy. ${ }^{7}$ Given these concerns, why did the Court not simply decline to consider these disputes, as it does with the vast majority of other appeals? In both cases, the Court essentially punted on the substantive issues, dismissing Gill for lack of standing and affirming the denial of a preliminary injunction in Benisek while providing little guidance on the underlying issues. ${ }^{8}$ Why, then, did the Court bother at all?

The answer is that the cases did not come to the Court through its normal discretionary certiorari jurisdiction. Instead, both Gill and Benisek involved direct appeals to the Supreme Court from three-judge district courts. ${ }^{9}$ The Court had no choice but to hear the cases. ${ }^{10}$ Chief Justice Roberts's concern was that if the Court recognized a claim for partisan gerrymandering, then all of these cases would reach the Supreme Court on mandatory direct appeal, not via the Court's discretionary certiorari jurisdiction where the Court could avoid ruling on them.

Under federal law, when three-judge district courts hear cases such as Gill and Benisek, a losing party may appeal directly to the Supreme Court, skipping the court of appeals. ${ }^{11}$ Thus, in Gill and Benisek, because the losing parties appealed the decisions, the Court had to do something with respect to the cases. Unlike a denial of certiorari, refusing to hear them would have been tantamount to a

1. 138 S. Ct. 1916 (2018).

2. 138 S. Ct. 1942 (2018) (per curiam).

3. For a discussion of the factors the Justices typically consider when deciding whether to grant or deny certiorari, see Stephen M. Shapiro et al., Supreme Court Practice 238-74 (10th ed. 2013).

4. 138 S. Ct. at 1922-24.

5. 138 S. Ct. at 1943.

6. Transcript of Oral Argument at 36-37, Gill v. Whitford, 138 S. Ct. 1916 (2018) (No. 16-1161).

7. See id. at $37-38$.

8. See Gill, 138 S. Ct. at 1931; Benisek, 138 S. Ct. at 1945.

9. Whitford v. Gill, 218 F. Supp. 3d 837, 843 (W.D. Wis. 2016) (three-judge court); Benisek v. Lamone, 266 F. Supp. 3d 799, 800 (D. Md. 2017) (three-judge court).

10. 28 U.S.C. $\S 1253$ (2012).

11. Id. 
summary affirmance on the merits, which lower courts likely would have considered to have at least some precedential value. Instead, the Court took a middle ground in Gill and Benisek, hearing them on the merits but providing little guidance on the doctrine of partisan gerrymandering beyond saying in Gill that plaintiffs must demonstrate individual harm from a map in a specific district. ${ }^{12}$ The Court held that the plaintiffs did not have standing for their statewide challenge but otherwise provided no analysis on the appropriate standard for a partisan gerrymandering claim. ${ }^{13}$ Justice Kagan, concurring for herself and three other Justices in Gill, offered a roadmap for plaintiffs looking to bring a successful claim in the future. ${ }^{14}$ Her proffered analysis can help the doctrine evolve for the next partisan gerrymandering case- - which the Court will once again be forced to consider on direct appeal. But the per curiam opinion in Benisek, affirming the denial of a preliminary injunction against Maryland's map, provides no help at all to future cases because it rested on purely procedural grounds. ${ }^{15}$

In fact, the Benisek opinion reads like a summary affirmance, although the Court at least provided some reasoning for its decision. Yet sometimes the Court will not even give full briefing or oral hearing to cases on direct appeal, instead summarily affirming them without explanation. In doing so, the Court creates precedent without saying what that precedent is.

As Gill and Benisek show, the three-judge district court is a unique and colorful component of the federal court system. ${ }^{16}$ Almost all cases in federal court are adjudicated in the familiar way before one district judge at the trial level, with review thereafter by a three-judge panel of a U.S. Court of Appeals, followed (in a small percentage of those cases) by discretionary, certiorari review in the U.S. Supreme Court. ${ }^{17}$ The three-judge district court, which Congress created in 1910 and amended substantially in 1937 and $1976,{ }^{18}$ departs from this pattern in several ways. Three judges - usually two district judges and one appellate judgehear the case at the trial level, and any appeal bypasses the court of appeals and is lodged directly with the Supreme Court, which at least ostensibly must decide the case on the merits. ${ }^{19}$

12. See Gill, 138 S. Ct. at 1932.

13. See id.

14. See id. at 1934-41 (Kagan, J., concurring) (discussing the ways a plaintiff could show an invalid partisan gerrymander, either through packing and cracking or based on a First Amendment infringement on the right of association).

15. Benisek, 138 S. Ct. at 1944-45.

16. See Joshua A. Douglas, The Procedure of Election Law in Federal Courts, 2011 UTAH L. REV. $433,433,456$ (discussing the situations in which Congress provided for three-judge district courts).

17. $I d$. at $455-56$.

18. Act of June 18, 1910, Pub. L. No. 61-218, ch. 309, § 17, 36 Stat. 539, 557 (codified at 28 U.S.C. $\S$ 2281) (repealed 1976); Act of Aug. 24, 1937, Pub. L. No. 75-352, ch. 754, § 3, 50 Stat. 751, 752 (codified at 28 U.S.C. § 2282) (repealed 1976); Act of Aug. 12, 1976, Pub. L. No. 94-381, §§ 2, 3, 90 Stat. 1119 (repealing 28 U.S.C. $\S \S 2281,2282$ ); id. § 3 (codified at 28 U.S.C. § 2284) (amending 28 U.S.C. § 2284).

19. For further detail on the history and operation of the three-judge district court, see infra Part I. 
The mechanism of three-judge district courts with direct appeal to the Supreme Court introduces two distinct questions of precedent. The first question is whether the Supreme Court's decision to summarily affirm (or reverse) a three-judge district court has any precedential effect. Other than binding the parties to the appeal, the precedential weight of these summary dispositions has long been unclear, although most observers believe that they are precedential to at least some extent. ${ }^{20}$ The second question asks whether precedent from a circuit court formally binds a three-judge district court from that circuit. A circuit court does not review the decision of a three-judge district court because the appeals process skips over the court of appeals. Should the circuit's precedents bind a three-judge district court that is not subject to the circuit's oversight?

On the first question, this Article advocates for the Court to hear direct appeals in full from three-judge district courts, rather than issue summary rulings without any explanation that may or may not be binding on future lower courts. The Court should fulfill its institutional role in giving full consideration to these appeals, as Congress intended in creating the direct appeal procedure from threejudge district courts. Assuming, however, that the Justices do not want to give full review to a particular case from a three-judge district court, the Court should be able to designate a summary ruling as nonprecedential, at least when the Court refuses to provide its rationale. Why force the Court's hand to set out binding precedent when it would rather let the issue percolate in the lower courts, especially in these highly charged political cases? The current middle ground of issuing a summary decision (typically an affirmance) that is precedential without providing any explanation or reasoning creates unnecessary confusion for lower courts and litigants. Judges on future three-judge district courts, and lawyers who appear before them, must somehow discern which part of the lower court's decision that the Supreme Court summarily affirmed was correct. Was it just the disposition or some of the reasoning as well?

The second question-does circuit precedent bind three-judge district courts? - considers a less noticed anomaly of practice in such courts. The conventional rules for hierarchical precedent are well settled. District courts must follow precedent from the circuit in which they sit but are not obliged to adhere to decisions of other circuits. ${ }^{21}$ Of course, all courts must follow precedent from the Supreme Court, but the Court denies most petitions for certiorari, ${ }^{22}$ and it is firmly established that such denials are entitled to no precedential weight as they express no "opinion upon the merits of the case." 23

20. See infra Section II.A.

21. Evan H. Caminker, Why Must Inferior Courts Obey Superior Court Precedents?, 46 STAN. L. REV. 817, 824-25 (1994).

22. See, e.g., SHAPIRO ET AL., supra note 3, at 237 (showing that the Court granted just $4.7 \%$ of certiorari petitions in the 2010 Term); The Supreme Court, 2017 Term: The Statistics, 132 HARV. L. REV. 447, 455 (2018) (showing that the Court granted just 4\% of certiorari petitions in the 2017 Term).

23. North Carolina v. N.C. State Conference of NAACP, 137 S. Ct. 1399, 1400 (2017) (mem.) (Roberts, C.J., statement respecting denial of certiorari) (quoting United States v. Carver, 260 U.S. 482, $490(1923))$. 
The rules of precedent for three-judge district courts, by contrast, are much less clear. Most three-judge district courts state that they are obliged to follow precedent from the circuit in which they sit, like all other district courts in the circuit, but offer little reasoning for this proposition. ${ }^{24}$ But other three-judge district courts do not find themselves so bound, on the theory that the three-judge district court operates outside of the usual hierarchical structure: appeals from those courts go directly to the Supreme Court, bypassing the courts of appeals. ${ }^{25}$ This difference between theories can be consequential given the common phenomenon of circuit splits. ${ }^{26}$

Thus, the rules of precedent are unclear for three-judge district courts from both descending and ascending perspectives. What precedential weight, if any, should all lower federal courts give to the Supreme Court's summary dispositions? And must three-judge district courts follow circuit precedent? Commentators have delved somewhat into the first issue of the precedential weight of Supreme Court summary dispositions, but the Court itself has been mostly equivocal. ${ }^{27}$ Scholars have acknowledged, but not explored, the second question on whether three-judge district courts must follow circuit precedent. ${ }^{28}$

This Article adds clarity to these debates and suggests their proper resolution. Part I recounts the history and present status of three-judge district courts. It highlights how, after congressional amendments to the three-judge district court statute in the 1970s, direct appeals of these cases have become a small part of the Supreme Court's overall docket but a significant portion of its election law caseload.

The remainder of this Article accepts the reality of the three-judge district court mechanism for certain cases, and instead of questioning their efficacy or soundness, seeks to improve their operation. In doing so, Part II addresses the first puzzle: what precedential weight should all courts give to the Supreme Court's summary dispositions of appeals from the decisions of three-judge district courts? We conclude that these summary decisions are entitled to zero or little precedential value, and therefore, the Justices need not feel obliged to hear these cases in

24. See, e.g., Parker v. Ohio, 263 F. Supp. 2d 1100, 1105 (S.D. Ohio 2003) (three-judge court) (offering the view that, even as a three-judge district court, "we are bound by precedent in this circuit"); see also infra Section III.A.

25. See, e.g., Jehovah's Witnesses in Wash. v. King Cty. Hosp., 278 F. Supp. 488, 504-05 (W.D. Wash. 1967) (three-judge court), aff' $d, 390$ U.S. 598 (1968) (noting that as a "special three-judge court ... . we are not bound by any judicial decisions other than those of the United States Supreme Court"); see also infra Section III.A.

26. The Seton Hall Circuit Review publishes an annual list of current circuit splits. See, e.g., Current Circuit Splits, 13 SETON Hall CIR. Rev. 275 (2017) (discussing approximately twenty circuit splits between August 1, 2016 and December 31, 2016).

27. See SHAPIRO ET AL., supra note 3, at 307-08 ("It thus seems fair to say that the whole Court agrees that summary dispositions are entitled to some weight, but to less than fully articulated decisions. ... Just what [such] dispositions hold has presented a problem for the lower courts."); see infra Section II.A.

28. See, e.g., Caminker, supra note 21, at 825 n.31 (suggesting that "[n]umerous 3-judge district courts follow their local court of appeals' precedents even though only the Supreme Court may review their decisions"). 
full if they want the issues to percolate in the lower courts first. They can simply summarily decide the case and bind only the litigants with an explicit statement to that effect. Yet there should be a presumption in favor of the Court providing legal guidance on the issue; that is, most of the time, the Court should set the case for oral argument and provide a full written opinion. This procedure will free the Court from hearing in full all direct appeals of cases from three-judge district courts, reserving its pronouncements for when it affirmatively chooses to resolve the underlying legal issues.

Part III addresses the other precedential puzzle: must three-judge district courts apply precedent from the circuit in which they sit? We conclude that three-judge district courts have no such obligation and can give all circuit precedent the weight they deem appropriate. That is, circuit precedent is not formally binding on three-judge district courts, although in many cases it will be highly persuasive.

In making these arguments, we do not mean to suggest that three-judge district courts are the most optimal tribunals for these cases, but only to say that, given their existence, the courts' current practice regarding precedent is untenable.

The three-judge district court procedure is a small part of the federal judiciary's docket, yet it plays a significant role because these courts handle cases involving redistricting and campaign finance, which are two highly charged issues that greatly impact participatory democracy. In fact, the issues that threejudge district courts resolve are often the most contentious and heated of any Supreme Court Term given their importance to the very operation of our democratic structure. Resolving how precedent works for these courts is therefore vital to ensure that the judiciary can properly adjudicate these disputes, ultimately helping our electoral system to function as fairly as possible.

\section{History and Operation of Three-Judge District Courts}

A. BRIEF HISTORY OF THREE-JUDGE DISTRICT COURTS

The three-judge district court has existed, in one form or another, since $1910 .^{29}$ Congress enacted the three-judge district court to hear constitutional challenges to state statutes. ${ }^{30}$ The procedure was a reaction to the Supreme Court's 1908 decision in Ex parte Young, in which the Court invalidated Progressive Era legislation regulating railroad rates. ${ }^{31}$ The theory behind the three-judge district court was that a single federal judge should not have the power to invalidate a state law; "[i]nstead, any such decision would be better discussed and decided by three federal judges, at least one of whom was a court of appeals judge, and perhaps even better received by the interested public." 32 Additionally, skipping the court of appeals stage and allowing a direct appeal to the Supreme Court would

29. Act of June 18, 1910, Pub. L. No. 218, ch. 309, § 17, 36 Stat. 539, 557 (codified at 28 U.S.C. $\S 2281$ ) (repealed 1976).

30. Id.

31. 209 U.S. 123, 148 (1908); see Michael E. Solimine, The Fall and Rise of Specialized Federal Constitutional Courts, 17 U. PA. J. Const. L. 115, 124 (2014).

32. Solimine, supra note 31 , at 124. 
produce a faster resolution on the constitutionality of a state statute, which was important to those concerned about the propriety of federal court encroachment upon state sovereignty. ${ }^{33}$

Congress expanded the three-judge district court in 1937 to apply to constitutional challenges to all laws rather than just state statutes. ${ }^{34}$ The amended threejudge district court was a minor outgrowth of President Franklin D. Roosevelt's Court-packing plan, in which Roosevelt sought to reshape the Supreme Court to uphold various aspects of his New Deal legislation. ${ }^{35}$ The idea to pack the Court failed, but Congress passed another part of the plan in 1937: the adoption of the three-judge district court for constitutional challenges to federal legislation. ${ }^{36}$ The theory was that an injunction against a federal statute was as significant as one against a state statute, such that a single federal judge should not have the sole power to enjoin a federal enactment. ${ }^{37}$

The three-judge district court comprised a significant portion of federal courts' work, particularly in the 1960s and 1970s, and at times appeals from these courts contributed up to a third of the Supreme Court's docket. ${ }^{38}$ Critics complained about both the administrative difficulty of convening three judges for a district court panel and the mandatory Supreme Court review of these courts' decisions. ${ }^{39}$ Congress acquiesced in 1976, abolishing the three-judge district court for all but a few substantive areas. ${ }^{40}$

Today, federal law requires three-judge district courts only for redistricting cases involving congressional or statewide reapportionments, ${ }^{41}$ certain campaign finance challenges, ${ }^{42}$ lawsuits under other statutes that Congress has found would benefit from the special three-judge district court procedure, ${ }^{43}$ and a few laws

33. See id. at 124-25; see also Michael E. Solimine, Congress, Ex parte Young, and the Fate of the Three-Judge District Court, 70 U. PITT. L. REV. 101, 114 (2008) (noting the "relatively rapid" progression of the case).

34. Act of Aug. 24, 1937, ch. 754, § 3, 50 Stat. 751, 752 (codified at 28 U.S.C. $§ 2282$ ) (repealed 1976).

35. See Solimine, supra note 31, at 123-24; see also Felix Frankfurter \& Adrian S. Fisher, The Business of the Supreme Court at the October Terms, 1935 and 1936, 51 HARV. L. REV. 577, 610-15 (1938) (discussing the interrelationship of the 1937 expansion of the three-judge district court's jurisdiction and the failed Court-packing plan).

36. Solimine, supra note 31 , at 123-24.

37. Id. at 125 (noting argument that "litigation attacking Acts of Congress should be of 'equal dignity' to suits covered by the three-judge district court and share in the presumed benefits of that court" (quoting David P. Currie, The Three-Judge District Court in Constitutional Litigation, 32 U. CHI. L. REV. 1, 11 (1964))).

38. Id. at 126.

39. Id. at $134-37$.

40. Act of Aug. 12, 1976, Pub. L. No. 94-381, §§ 2, 3, 90 Stat. 1119 (repealing 28 U.S.C. §§ 2281, 2282).

41. 28 U.S.C. $§ 2284(a)$ (2012) (“A district court of three judges shall be convened when otherwise required by Act of Congress, or when an action is filed challenging the constitutionality of the apportionment of congressional districts or the apportionment of any statewide legislative body.").

42. Bipartisan Campaign Reform Act of 2002, Pub. L. No. 107-155, § 403(a), 116 Stat. 81, 113.

43. Statutes that fall into this category "include the Balanced Budget and Emergency Deficit Control (Gramm-Rudman-Hollings) Act of 1985, [Pub. L. No. 99-177, § 274(a), 99 Stat. 1037, 1098] the Cable 
involving the appointment of sitting members of Congress to cabinet positions. ${ }^{44}$ Members of Congress who supported the use of three-judge district courts for these cases believed that having three judges decide the disputes from the outset would better protect important rights, such as the right to vote. ${ }^{45}$

Redistricting cases now comprise the bulk of three-judge district court adjudication, although campaign finance cases using this procedure also continue to be influential. ${ }^{46}$ Indeed, some of the most controversial redistricting and campaign finance cases of the past decade_-including McConnell v. FEC, ${ }^{47}$ Citizens United v. FEC,$^{48}$ Evenwel v. Abbott, ${ }^{49}$ and Abbott v. Perez ${ }^{50}$ - arose from three-judge district courts.

\section{B. MECHANICS OF THREE-JUDGE DISTRICT COURTS}

Congress mandated specific requirements for the operation of three-judge district courts. A party initiating a lawsuit that would qualify for a three-judge

Television Consumer Protection and [Competition] Act of 1992, [Pub. L. No. 102-885, § 23, 106 Stat. 1460, 1500] the Communications Decency Act of 1996, [Pub. L. No. 104-104, § 561, 110 Stat. 133, 142-43] . . . and the census reform legislation passed in 1998 [Departments of Commerce, Justice, and State, the Judiciary, and Related Agencies Appropriations Act of 1998, Pub. L. No. 105-119, § 209(e), 111 Stat. 2440, 2482]." Solimine, supra note 31, at 130.

More recently, several members of Congress included the three-judge district court mechanism in their bipartisan legislative proposal to protect a special counsel from being fired. See Special Counsel Independence and Integrity Act, S. 2644, 115 th Cong. § 2(e)(2) (2018).

44. These laws involve the so-called "Saxbe Fix," which Congress enacted in response to President Nixon's nomination of then-Senator William Saxbe for Attorney General. Opponents argued that the appointment would violate the Constitution's Emoluments Clause because Saxbe had voted for an increase in the salary and benefits for the office to which he was appointed. See Solimine, supra note 31, at 131 .

45. See S. REP. No. 94-204, at 7-9 (1975), as reprinted in 1976 U.S.C.C.A.N. 1988, 1996 ("[I]t is the judgment of the committee that [issues such as legislative apportionment] are of such importance that they ought to be heard by a three-judge court."). Congress also included a mechanism for three-judge district courts in the Civil Rights Act of 1964, in part to better protect civil rights. See H.R. REP. No. 88914, at 2125 (1964), as reprinted in 1964 U.S.C.C.A.N. 2391, 2490-91 (additional views of Rep. McCulloch et al. noting that "[s]ingle judges have in some instances refused to act in the face of convincing evidence" and that three judges would provide a "balance and broad range of views" and therefore a "greater willingness to safeguard the individual's right to vote").

46. Until the Court's decision in Shelby County v. Holder, 570 U.S. 529 (2013), which invalidated the preclearance formula of the Voting Rights Act of 1965 (VRA), three-judge district courts were also convened in declaratory judgment actions under section 5 of the VRA by covered jurisdictions seeking preclearance of any voting changes. See 52 U.S.C. § 10304(a) (2012) ("Any action under this section shall be heard and determined by a court of three judges in accordance with the provisions of section 2284 of title 28 and any appeal shall lie to the Supreme Court.”).

This provision is still on the books, but without a coverage formula, no jurisdictions are subject to section 5's preclearance requirement, meaning that this use of the three-judge district court is currently obsolete unless a court decides to "bail in" a particular jurisdiction under the rarely-used Section 3 of the VRA after a finding of intentional discrimination. Edward K. Olds, Note, More Than "Rarely Used" : A Post-Shelby Judicial Standard for Section 3 Preclearance, 117 CoLuM. L. ReV. 2185, 2188 (2017); see, e.g., Jeffers v. Clinton, 740 F. Supp. 585 (E.D. Ark. 1990) (three-judge court) (deciding whether to apply the remedy of preclearance under section 3(c) of the VRA).

47. 540 U.S. 93,132 (2003).

48. 558 U.S. $310,319(2010)$.

49. 136 S. Ct. 1120,1125 (2016).

50. 138 S. Ct. 2305, 2313 (2018). 
district court must file a request with the district judge to convene the special court. ${ }^{51}$ The single district judge determines whether "three judges are not required." ${ }^{52}$ The Supreme Court recently clarified this statement to mean simply that the judge must "first examin[e] the allegations in the complaint" to ensure that the case qualifies under the statute and that there is federal jurisdiction..$^{53}$ If the case qualifies-because, for example, it is a redistricting dispute involving a congressional or statewide apportionment - then the judge must notify the chief judge of the circuit. ${ }^{54}$ The chief judge will then appoint two other judges, one of whom must be a circuit judge, to join the initial district judge on the three-judge district court panel. ${ }^{55}$ The original judge may conduct pretrial proceedings and enter preliminary orders but may not render a decision on the merits or grant a motion to dismiss for failure to state a claim. ${ }^{56}$ The three-judge district court panel acts as a trial court, making findings of fact and conclusions of law.

Final judgments of the three-judge district court are appealable directly to the Supreme Court, skipping the intermediate court of appeals stage. ${ }^{57}$ The Court may then "note probable jurisdiction," ${ }^{, 58}$ meaning that it will conduct a full hearing, or summarily affirm or reverse, "but either way the Supreme Court must decide the dispute" on the merits. ${ }^{59}$

Appeals from the decisions of three-judge district courts have represented a significant portion of the Supreme Court's election law docket. From 2000 to 2015, nearly half of the Court's sixty election law cases came on mandatory

51. 28 U.S.C. $§ 2284$ (b)(1) (2012).

52. Id.

53. Shapiro v. McManus, 136 S. Ct. 450, 455 (2015). In the interest of full disclosure, we note that we jointly filed an amicus brief in Shapiro supporting the petitioners.

54. 28 U.S.C. $\$ 2284(b)(1)$.

55. Id. The chief judge has full discretion to choose the other two judges-usually one circuit judge and one district judge - to comprise the three-judge district court. Although it is theoretically possible that the chief judge might select judges with ideology in mind, we are not aware of any studies that systematically examine whether this bias occurs in practice. There is some evidence that some "stacking" of three-judge district court panels took place in the Fifth Circuit in the 1950s and early 1960s, purportedly to avoid permitting some conservative district judges from serving on desegregation cases. For further discussion, see Michael E. Solimine, The Three-Judge District Court in Voting Rights Litigation, 30 U. Mich. J.L. ReForm 79, 110-11 (1996). For that article, Professor Solimine contacted the chief judges of each of the circuits responsible for selecting the remaining two members of the courts. Of those chief judges or circuit executives who responded, most indicated that chief judges would assign judges from the state in question, and although some indicated that chief judges would take into account some kind of political "balance," there was no evidence in the responses of "stacking" or "packing" the panels. Id. at 113 (describing and reporting the results of the survey).

56. 28 U.S.C. $\S 2284$ (b)(3); Shapiro, 136 S. Ct. at 455.

57. 28 U.S.C. $§ 1253(2012)$.

58. SuP. CT. R. 18.12.

59. Douglas, supra note 16, at 456. Sometimes the Court will "postpone" the consideration of jurisdiction while still agreeing to hear the case, as it did in Gill, the partisan gerrymandering case from Wisconsin. Gill v. Whitford, 138 S. Ct. 1916, 1926 (2018) (noting that the Court "stayed the District Court's judgment and postponed consideration of [its] jurisdiction"). 
review from three-judge district courts. ${ }^{60}$

The unique procedures of three-judge district courts raise two fundamental questions about their operation. ${ }^{61}$ First, are the Supreme Court's summary rulings on appeals from three-judge district courts binding precedent on lower courts? Second, must these courts follow appellate court decisions in the circuit in which they sit? These procedural questions go to the heart of how three-judge district courts function, giving them outsized importance for the underlying substantive issues - especially on redistricting and campaign finance-that these courts resolve. The remainder of the Article provides some answers, explaining why we should not consider the Supreme Court's summary dispositions as precedential, except in a very limited way, and why prior circuit precedent should not bind three-judge district courts.

\section{The Precedential Weight of the Supreme Court's Summary Dispositions of Appeals from Three-Judge District Courts}

Under the statute that creates three-judge district courts, the losing party may appeal their decisions directly to the Supreme Court. ${ }^{62}$ On its face this procedure is different from the typical process involving a writ of certiorari, through which the Court can simply deny the petition without creating new precedent.

In the normal case involving an appeal from a circuit court of appeals or state supreme court, the losing party below seeks a writ of certiorari, which asks the Supreme Court to review the dispute. The Court has full "judicial discretion" 63 on whether to set the case for briefing and oral argument; Supreme Court practice requires four of the nine Justices to grant the writ and hear a case. ${ }^{64}$ The Court will take a case "only for compelling reasons," such as the presence of a circuit

60. Douglas, supra note 16, at 458; Richard L. Hasen, Election Law's Path in the Roberts Court's First Decade: A Sharp Right Turn but with Speed Bumps and Surprising Twists, 68 StAn. L. ReV. 1597, 1621 (2016).

61. The purpose of this Article is not to question the propriety of three-judge district courts. We have done so previously in other articles. For instance, one of us has highlighted the benefits and disadvantages of these courts:

Three-judge district courts, with direct review to the Supreme Court, ultimately have some virtues that are important in election law cases: quick resolution, an air of greater accuracy and legitimacy, and the symbolism of increased scrutiny for particularly important cases, to name a few. But they also have less desirable features, such as forcing the Supreme Court to decide an issue earlier than it may wish, a misallocation of tasks in the judicial decisionmaking process, and the possible perpetuation of the view that ideology drives the decisions,

Douglas, supra note 16, at 467 . Our focus here, instead, is to propose solutions to assist the operation of these courts given that they exist.

62. 28 U.S.C. $\$ 1253$ (2012).

63. SuP. CT. R. 10.

64. See, e.g., Ferguson v. Moore-McCormack Lines, Inc., 352 U.S. 521, 560 (1957) (Harlan, J., concurring and dissenting) (explaining that "the whole philosophy of the 'rule of four,'... is that any case warranting consideration in the opinion of such a substantial minority of the Court will be taken and disposed of"). The Rule of Four is not found in a formal Supreme Court Rule, but rather is a reflection of long-standing Court practice. See SHAPIRO ET AL., supra note 3, at 325-29 (discussing Rule of Four in certiorari decisions); id. at 364-65 (same for direct appeals). 
split or an important question of federal law. ${ }^{65}$ A denial of certiorari-the fate of most such requests—-says nothing about the underlying merits of the decision and has no precedential effect. ${ }^{66}$

The procedure for an appeal of a three-judge district court decision, however, is different. Because an appeal from a three-judge district court to the Supreme Court is the only permitted appeal for that litigation, the Court is under some obligation to resolve it on the merits ${ }^{67}$ The Court first determines whether it should consider the case fully, which would include further briefing and an oral argument. ${ }^{68}$ To do so, the Court will "note probable jurisdiction," ${ }^{, 69}$ which seems similar to how the Court grants a writ of certiorari. ${ }^{70}$ If the Court decides not to give full consideration to the appeal, it will summarily affirm or reverse, almost always with a brief order to that effect but with no explanatory opinion accompanying that order. ${ }^{71}$ Unlike a denial of certiorari, a summary disposition is ostensibly "on the merits," especially given that it is the only appeal available in the case. $^{72}$ Thus, although the processes for denying certiorari and for summarily affirming the decision of a three-judge district court look similar, the effect of these orders is quite different: the denial of certiorari is not precedential at all, whereas a summary affirmance or reversal has some precedential weight.

Yet it is not clear how much precedential weight, if any, the legal system should give to the Court's supposedly "on the merits" summary dispositions of direct appeals from three-judge district courts. In this Part, we first canvass that confusing body of law. We then expound upon the problems with this approach and provide advice to the Court on how to reform its practice of summary dispositions. We conclude that the Court should set more of these cases for full briefing and oral argument, but also suggest that if the Court wants to issue a summary disposition, it should make clear that its decision (and the decision of the threejudge district court under review) is not precedential and resolves only the precise dispute between the parties in that case.

\section{A. CURRENT JURISPRUDENTIAL STATUS OF SUMMARY DISPOSITIONS FROM THE SUPREME COURT}

In a judicial system with multiple levels, a losing party ordinarily may appeal to a higher court as of right, with an "appeal" suggesting full briefing, the potential of oral argument, and an explanatory opinion giving a rationale for a plenary disposition. ${ }^{73}$ In the federal system, in most cases a losing party at the district

65. SUP. CT. R. 10.

66. SHAPIRO ET AL., supra note 3, at 335-39.

67. ShapIRo ET AL., supra note 3, at 300 (by permitting "appeals," Congress suggested "that the losing party may obtain review on the merits by a higher court as of right, not merely a discretionary determination as to whether the higher court will consider the case.").

68. Sup. CT. R. 18.12.

69. Id.

70. See SHAPIRO ET AL., supra note 3, at 363-65.

71. See id. at 365-67.

72. Id. at 366 .

73. See id. at 300-01. 
court may appeal, as of right, to the court of appeals. ${ }^{74}$ To reach the Supreme Court, the losing party case must file a writ of certiorari, which the Court has the discretion to accept or deny.

Yet a small set of cases - those that arise from three-judge district courtscome to the Supreme Court via direct appeal from the district court. ${ }^{75}$ Under the federal statute that created these courts, a direct appeal to the Supreme Court is the only appeal allowed, which is why the Court does not have the discretion to avoid these cases and litigants have a right to this appeal. ${ }^{76}$ But the Supreme Court does not always give these cases full review. Instead, the Court often uses summary dispositions (usually affirmances) to resolve these direct appeals. ${ }^{77}$ The Court has defended its approach on the ground that only summary treatment is necessary because such cases lack a "substantial federal question" to decide. ${ }^{78}$

This practice has made it difficult to discern what precedential weight future courts should afford to such dispositions. At one point, there appears to have been an understanding that lower courts should treat summary dispositions the same as denials of certiorari, that is, with no precedential value. ${ }^{79}$

In several decisions from the 1970s, however, the Court departed from that understanding and held that summary affirmances of appeals, unlike certiorari denials, were "on the merits, entitled to precedential weight." ${ }^{80}$ But the Court "immediately diluted the effect" of its pronouncement by stating "that [such] summary dispositions will not be accorded the full weight of decisions in which the issues were fully explored." $" 81$

In short, it "seems fair to say that the whole Court agrees that summary dispositions are entitled to some weight, but to less than fully articulated decisions. . . . [T] he Justices feel less intellectual commitment to such decisions, even though they are a disposition on the merits." 82 In other words, the Court has tried to find a middle ground, giving some precedential value to summary dispositions, which

74. See 28 U.S.C. $\$ 1291$ (2012).

75. Under various statutes, litigants used to file direct appeals to the Supreme Court in certain cases from single district judges and state supreme courts involving federal constitutional questions. Congress repealed those statutes in the 1970s and 1980s. By 1988, Congress left the three-judge district court as the only tribunal regularly supplying direct appeals to the Supreme Court. See, e.g., The Supreme Court, 2017 Term, The Statistics, 132 HARV. L. REV. 447, 457 (2018) (noting that of the sixty nine cases decided on the merits in the 2017 Term, only two came from direct appeals).

76. See 28 U.S.C. $\$ 1253$ (2012).

77. See, e.g., Republican Party of La. v. FEC, 219 F. Supp. $3 d 86$ (D.D.C. 2016) (three-judge court), aff' d, 137 S. Ct. 2178 (2017) (mem.); Bluman v. FEC, 800 F. Supp. 2d 281 (D.D.C. 2011) (three-judge court), aff' d, 565 U.S. 1104 (2012) (mem.).

78. See, e.g., Hicks v. Miranda, 422 U.S. 332, 343-45 (1975) (quoting Ohio ex rel. Eaton v. Price, 360 U.S. 246, 247 (1959) (per curiam) (statement of Brennan, J.)); SHAPIRO ET AL., supra note 3, at 302-03.

79. See SHAPIRO ET AL., supra note 3, at 302-03.

80. Meek v. Pittenger, 421 U.S. 349, 367 n.16 (1975); see also Edelman v. Jordan, 415 U.S. 651, 671 (1974) (stating that "summary affirmances obviously are of precedential value").

81. SHAPIRO ET AL., supra note 3, at 306 (citing Ashland Oil, Inc. v. Caryl, 497 U.S. 916, 920 n.* (1990)).

82. Id. at 307 (citing San Antonio Indep. Sch. Dist. v. Rodriguez, 411 U.S. 1 (1973); McGowan v. Maryland, 366 U.S. 420 (1961)). 
are supposedly on the merits, but failing to accord them the same weight as other decisions that have a full opinion.

Most of the Court's decisions discussing the precedential weight of summary dispositions deal with how the Court itself should treat its own summary rulings. But the Court has made clear that lower courts should also consider such summary dispositions as precedential in the same way. ${ }^{83}$ In Hicks $v$. Miranda, for instance, the Court chastised a lower court for "disregard[ing]" a summary affirmance by noting,

We were not obligated to grant the case plenary consideration, and we did not;
but we were required to deal with its merits. We did so by concluding that the
appeal should be dismissed because the constitutional challenge to the
California statute was not a substantial one. The three-judge court was not free
to disregard this pronouncement. As Mr. JUSTICE BRENNAN once observed,
"[v]otes to affirm summarily, and to dismiss for want of a substantial federal
question, it hardly needs comment, are votes on the merits of a case ...."

Not surprisingly, given that the Court has been vague on the level of precedential weight these decisions should engender, lower courts have also expressed confusion as to what aspects of a summary decision they must follow. ${ }^{85}$ Without an explanatory opinion, it is unclear whether all or some of the Justices agreed on a rationale for affirming the lower court, or even what rationale sustained the decision. ${ }^{86}$ The Court has unhelpfully stated that "[a] summary disposition affirms only the judgment of the court below, and no more may be read into our action than was essential to sustain that judgment." 87 This apparently means that the Court is not necessarily adopting the reasoning of the lower court when summarily affirming. ${ }^{88}$

But how can a lower court determine what was "essential" for the Supreme Court to sustain the judgment? The Supreme Court has stated that the lower court should assess the affirmance "in light of all of the facts" and compare those facts to the facts presented in the separate, new case to determine if the facts of the two cases are "very different." 89 This instruction seemingly means that the subsequent lower court should determine if the constitutional issues in the two cases are the same,${ }^{90}$ though the scope of the required overlap between the two cases is elusive. To make this comparison, moreover, "lower court judges must have before them

83. ShapIRO ET AL., supra note 3, at 308 (discussing Hicks v. Miranda, 422 U.S. 332 (1975) and Tully v. Griffin, Inc., 429 U.S. 68 (1976)).

84. 422 U.S. at 344 (quoting Ohio ex rel. Eaton v. Price, 360 U.S. 246, 247 (1959)).

85. See SHAPIRO ET AL., supra note 3, at 309-11 (discussing how uncertainty in Supreme Court decisions can lead to uncertainty in lower courts on the weight to be given to summary affirmances).

86. Id. at 309.

87. Anderson v. Celebrezze, 460 U.S. 780,785 n.5 (1983).

88. See SHAPIRO ET AL., supra note 3, at 309 (citing Fusari v. Steinberg, 419 U.S. 379, 391-92 (1975) (Burger, C.J., concurring)).

89. Mandel v. Bradley, 432 U.S. 173, 177 (1977) (per curiam).

90. Id. at 180 (Brennan, J., concurring). 
most if not all of the appeal papers in the earlier proceedings, and must not rely too much on the rationale expressed in the lower court opinions in the earlier cases." M1 Many judges and lawyers would "find this approach to prior Supreme Court summary actions both difficult and hazardous to follow." 92 As Justice Sotomayor wrote in dissent in a recent case involving whether the Court had jurisdiction over an interlocutory appeal from a three-judge district court, "[s]imple is thus the name of the game when it comes to jurisdictional rules." ${ }^{93}$ Yet the current approach of using summary dispositions without explanation is anything but simple.

Some recent decisions illustrate well the implications of the Supreme Court's summary disposition jurisprudence. In Cox v. Larios, the Court summarily affirmed an appeal from a three-judge district court in a reapportionment case involving the redrawing of state legislative lines. ${ }^{94}$ Prior Court decisions had left unclear how much and under what circumstances legislatures could deviate from strict mathematical one-person, one-vote equality in drawing state legislative districts. Although not models of consistency, those prior cases arguably established that the one-person, one-vote principle allowed population deviances of up to ten percent, meaning that a deviation of less than ten percent was permissible. ${ }^{95}$ Yet the lower court in Cox struck down a state map in which the deviances were slightly less than ten percent, ${ }^{96}$ finding that such deviances existed for illegitimate, strictly partisan grounds rather than for nonpolitical reasons, such as tracking the lines of existing political subdivisions. ${ }^{97}$ The Court summarily affirmed without a written explanation. ${ }^{98}$ The decision left the state of the law on ten percent safe harbors unclear. ${ }^{99}$ Justice Stevens wrote a concurring opinion and Justice Scalia authored a dissent, exacerbating the lack of clarity from the Court's decision given that the majority did not provide a rationale for its summary affirmance. $^{100}$

91. SHAPIRO ET AL., supra note 3, at 311.

92. Id.

93. Abbott v. Perez, 138 S. Ct. 2305, 2342 (2018) (Sotomayor, J., dissenting).

94. Larios v. Cox, 300 F. Supp. 2d 1320 (N.D. Ga.), aff' d, 542 U.S. 947 (2004) (per curiam).

95. See Michael R. Dimino et Al., Understanding Election Law and Voting Rights 40-42 (2017) (discussing Karcher v. Daggett, 462 U.S. 725 (1983), Gaffney v. Cummings, 412 U.S. 735 (1973), Mahan v. Howell, 410 U.S. 315 (1973), and Kirkpatrick v. Preisler, 394 U.S. 526 (1969)).

96. See Larios, 300 F. Supp. 2d at 1322 (finding that the reapportionment plan "deviates from the population equality by a total of $9.98 \%$ of the ideal district population").

97. See id.

98. 542 U.S. at 947.

99. See Dimino ET AL., supra note 95, at 42; Michael E. Solimine, Institutional Process, Agenda Setting, and the Development of Election Law on the Supreme Court, 68 OHIO ST. L.J. 767, 792-93 (2007).

100. Justice Stevens, joined by Justice Breyer, concurred in Cox on the basis that the actions by the state legislature amounted to impermissible partisan gerrymandering, reiterating a position he took in his dissent earlier that year in Vieth v. Jubelirer, 541 U.S. 267, 317 (2004) (Stevens, J., dissenting). Cox, 542 U.S. at 949-51 (Stevens, J., concurring). Justice Scalia dissented on the basis that partisan gerrymandering was nonjusticiable under his opinion for a plurality of the Court in Vieth, and that oneperson, one-vote claims involving "minute population deviations" should not be permitted to masquerade as partisan gerrymandering claims. Id. at 951-52 (Scalia, J., dissenting). 
A decade later, the Court in Harris v. Arizona Independent Redistricting Commission briefly revisited the issue, explaining its decision in Cox by simply referring to the reasoning of the three-judge district court in that case. ${ }^{101}$ It appeared from Harris that by summarily affirming the three-judge district court's decision in Cox, the Court had essentially adopted that court's rationalealthough the Court did not make this explicit or clear when it summarily affirmed the decision in Cox. The Court could have dispelled much of this confusion if it had given the appeal plenary treatment in the first instance, explained specifically what aspect of the lower court it was affirming, or directly stated that its summary affirmance was not precedential at all.

Another example of the implications that arise from the Court's summary disposition jurisprudence comes from the campaign finance world, where the Court is statutorily obliged to review three-judge district court decisions that consider constitutional challenges to various provisions of the Bipartisan Campaign Reform Act of 2003 (BCRA). ${ }^{102}$ The Court has given full consideration to a stream of challenges that initially went before three-judge district courts in the District of Columbia, complete with full explanatory opinions. ${ }^{103}$ But in at least two significant cases, the lower courts rejected the challenges and the Supreme Court summarily affirmed those decisions without explanation. One such case concerned the BCRA provision limiting federal election spending by foreigners ${ }^{104}$ while the other concerned the BCRA provision limiting "soft-money" campaign contributions to state and local political parties. ${ }^{105}$ In both cases, some observers argued that the summary dispositions were surprising because prior decisions striking down other BCRA provisions had arguably cast doubt on the constitutional validity of these parts of the law. ${ }^{106}$ Yet the status of these two summary affirmances as precedential for future cases remains unclear. For such highprofile legal challenges involving important political issues, the Court should provide more than just a perfunctory summary affirmance.

101. 136 S. Ct. 1301, 1310 (2016). The Court made no mention of the separate opinions in Cox.

102. Bipartisan Campaign Reform Act of 2002, Pub. L. No. 107-155, § 403(a), 116 Stat. 81, 113.

103. See, e.g., Davis v. FEC, 554 U.S. 724 (2008), rev'g, 501 F. Supp. 2d 22 (D.D.C. 2007) (three judge court); Wis. Right to Life, Inc. v. FEC, 546 U.S. 410 (2006) (per curiam), vacating, 2004 WL 3622736 (D.D.C. 2004) (three judge court).

104. Bluman v. FEC, 800 F. Supp. 2d 281 (D.D.C. 2011) (three-judge court), aff'd, 565 U.S. 1104 (2012) (mem.).

105. Republican Party of La. v. FEC, 219 F. Supp. 3d 86 (D.D.C. 2016) (three-judge court), aff' $d$, 137 S. Ct. 2178 (2017) (mem.). Justices Thomas and Gorsuch dissented from the summary affirmance and would have set the case for full argument. 137 S. Ct. at 2178.

106. In response to Bluman, some observers felt that the broad rationale of Citizens United cast serious doubt on the provision excluding foreign contributions. See Richard L. Hasen, Citizens United and the Illusion of Coherence, 109 MicH. L. REV. 581, 605-10 (2011); Richard Hasen, Why Banning Russian Facebook Ads Might Be Impossible, PoLITICO (Sept. 26, 2017), https://www.politico.com/ magazine/story/2017/09/26/russian-facebook-ads-regulation-215647 [https://perma.cc/7QTG-PU3Z] In response to the Republican Party case, some observers were surprised that the Court denied full review, because the provision in question was arguably unconstitutional given the rationale of Citizens United and other BCRA cases. See Kenneth P. Doyle, 'Soft Money' Rules Upheld by Supreme Court, 85 U.S.L.W. 1607, 1607-08 (2017) (discussing views of noted election law litigator James Bopp). 
In the remainder of this Part, we address why the Court should change its summary disposition practice and what the Court should do differently.

\section{B. WHY THE SUPREME COURT SHOULD CHANGE ITS APPROACH TO SUMMARY AFFIRMANCES OF THREE-JUDGE DISTRICT COURTS}

The Supreme Court's current summary disposition practice has inspired some forceful opposition - with which we ultimately agree. On the Court itself, for example, Justice William Brennan stated that if summary affirmances have any precedential weight, even if less than a full opinion, then "at a minimum we have the duty to provide some explanation of the issues presented in the case and the reasons and authorities supporting our summary dispositions."107 Although Justice Brennan expressed his belief that this obligation existed for "every case," he also made clear that the Court had a particular responsibility for cases "presenting novel issues or where there is disagreement among us as to the grounds of the disposition."

The leading treatise on Supreme Court practice echoes Justice Brennan's position on this issue. ${ }^{109}$ The treatise's authors conclude that lower courts and the bar would benefit from further explanation, arguing that it would help, for example, if 'instead of merely saying 'affirmed,' the Court briefly stated the ground for its ruling, or cited a case that would indicate the ground. Although this would make summary disposition slightly less summary, the additional understanding it would produce would reduce the amount of future litigation."110 This benefit, they continue, "would likely outweigh the additional burden that would be imposed," especially given the relatively few direct appeals that now go to the Court. ${ }^{11}$

Sound institutional reasons support abolishing, or at least limiting, the use of precedential summary affirmances for direct appeals from three-judge district courts. Summary dispositions, which may or may not have precedential weight, have caused considerable confusion not only for the Court itself, but also for lower court judges and attorneys practicing before three-judge district courts. How should future litigants decipher the cryptic one-line decisions that are

107. Colo. Springs Amusements, Ltd. v. Rizzo, 428 U.S. 913, 922 (1976) (Brennan, J., dissenting from denial of certiorari).

108. Id.

109. See SHAPIRO ET AL., supra note 3, at 311.

110. Id. Requiring the Supreme Court to provide some rationale for its decision is not likely to lead to much further delay because the Court decides all of its cases within a single Term running from October to June. Moreover, by skipping the court of appeals stage, the litigation is already streamlined, which was one of the goals behind Congress's creation of three-judge district courts. See Douglas, supra note 16, at 460-62 (showing how long it takes the Supreme Court to resolve appeals from three-judge district courts, ranging from about four months to a little over a year and a half).

111. SHAPIRO ET AL., supra note 3, at 311. Relatedly, one commentator has expressed concerns with the Court's frequent use of summary orders to dispose of requests for stays of lower court decisions concerning the death penalty, pending elections, and other cases needing rapid treatment. See William Baude, Foreword: The Supreme Court's Shadow Docket, 9 N.Y.U. J.L. \& LiBerTy 1, 3 (2015). But in many of those cases, there is a need for swift rulings and virtually no time to prepare even a short explanatory opinion (though the Court could release one later). In contrast, there is rarely such a need for swiftness to decide direct appeals in three-judge district court cases. 
currently, and confusingly, described as being "on the merits?" Are they fully precedential, entitled to only some weight, or not precedential at all?

Nevertheless, there are several possible reasons why the Court might choose to maintain the status quo of summarily affirming those cases in which it does not wish to provide more guidance. First, given the statutory changes in the 1970s and 1980s that limited the kinds of cases that warrant a three-judge district court, there are relatively few cases that arrive at the Supreme Court on direct appeal. ${ }^{112}$ Thus, even if one concedes that the Court's practice leads to jurisprudential confusion, its approach concerns only a small number of cases and certainly far fewer than the large number of such cases and appeals in the 1960s and 1970s. These cases, however, go to the heart of representative democracy, so they are arguably different from other legal disputes, which is why Congress gave them a special procedure in the first place. Cases about democratic processes are sufficiently consequential that we should be concerned about the confusion that surrounds them.

Second, one might defend the summary affirmance practice as a nod to the legal acumen of three lower federal court judges, meaning that another multimember court need not spend as much time reviewing the lower court's decision. ${ }^{113}$ Yet this same rationale might also apply to the Court's denials of certiorari from three-judge appellate panels on the circuit courts, but those orders are not precedential.

Third, as a practical matter, summary dispositions of direct appeals, like denials of certiorari, may permit the Court to act strategically and dodge the need to confront directly a particularly controversial or politically charged issue. ${ }^{114}$ But treating a summary disposition as potentially precedential compromises that strategy.

Fourth, the Court's frequent invocation of the "narrow" construction it has given to the Three-Judge Court Act might also support its approach to summary dispositions of these appeals. ${ }^{15}$ Without apology, the Court has stated that a narrow construction is necessary to "minimize[e] the mandatory docket of this Court

112. See supra notes $38-44$ and accompanying text.

113. This rationale might ring true despite the fact that the formality of an "appeal" forces the Court to indulge the legal fiction that such dispositions are "on the merits." $C f$. Frederick Schauer, Giving Reasons, 47 StAn. L. Rev. 633, 651-53 (1995) (linking explanations in judicial opinions with rule of law values).

114. See generally Erin F. Delaney, Analyzing Avoidance: Judicial Strategy in Comparative Perspective, 66 DUKE L.J. 1, 17-18 (2016) (discussing denials of certiorari and other mechanisms where the Court, without explanation, can avoid confronting difficult or controversial issues). As one of us has suggested, the Court seems to suffer from "BCRA-fatigue" and may not wish to issue full opinions on the seemingly endless stream of constitutional challenges to various provisions of the BCRA. Solimine, supra note 99, at 779. See also Gonzalez v. Automatic Emps. Credit Union, 419 U.S. 90, 99 n.17 (1974) (stating that many three-judge district court cases that are summarily affirmed "would benefit from the normal appellate review").

115. Solimine, supra note 33, at 134-35, 140 (discussing the overtly narrow construction the Court gave to the statute). 
in the interests of sound judicial administration." 116 The use of summary affirmances to decide direct appeals is consistent with that limited construction, insofar as it streamlines the Court's involvement in these cases. But again, that cursory review is at odds with the special procedures Congress created for these kinds of cases, particularly those that affect elections.

Finally, whether intended or not, perhaps the Court's current practice of using summary affirmances has the virtue of signaling to lower courts that they may adopt reasonable but narrower readings of Court precedent, especially if that precedent comes from a summary disposition and not a full opinion. Such narrowing may have social benefits when the Court's precedents in question are obsolete or have had harmful consequences. ${ }^{117}$ This narrowing allows a middle ground between lower courts dogmatically applying Court precedent in all circumstances and the Court having to decide whether to overrule one of its own cases. ${ }^{118}$ The Court could summarily affirm, obliquely upholding a three-judge district court decision, without explicitly adopting its narrowing construction. Again, however, that narrowing from below comes at a cost: opacity in an area such as election law, where clarity is a virtue.

\section{REFORMING THE COURT'S SUMMARY DISPOSITION PRACTICE}

We agree with the reformers: the Court should eliminate its middle-ground, confusing position of issuing summary decisions while claiming that they have some (but perhaps not full) precedential weight. Instead, the Court should take one of two clearer paths: (1) either treat a direct appeal of a decision from a threejudge district court like a grant of certiorari and set the case for full briefing and

116. Gonzalez, 419 U.S. at 98 (citing Phillips v. United States, 312 U.S. 246 (1941)); see also Abbott v. Perez, 138 S. Ct. 2305, 2324 (2018) (reiterating "that $§ 1253$ must be strictly construed"). But see id. at 2335-37, 2339 (Sotomayor, J., dissenting) (accusing the majority of not engaging in strict construction).

117. See generally Richard M. Re, Narrowing Supreme Court Precedent from Below, 104 GEO. L.J. 921 (2016) (providing an extended discussion and defense of this option).

118. Professor Re does not discuss at any length how the institution of the three-judge district court, coupled with direct appeals, fits in the "narrowing from below" model. See id. Nonetheless, it is significant that he mentions, as a "classic example" of when "a lower court might predict that the higher court will overrule or otherwise set aside its own case law," the case of Barnette v. West Virginia State Board of Education, 47 F. Supp. 251 (S.D. W. Va. 1942) (three-judge court), aff' d, 319 U.S. 624 (1943). Re, supra note 117 , at 940 \& n.91. The Supreme Court had previously held that public school students could be forced to salute the flag or recite the Pledge of Allegiance. Minersville Sch. Dist. v. Gobitis, 310 U.S. 586 (1940). Subsequently, the three-judge district court in Barnette, considering the same issue, held for the school children, predicting that the Supreme Court would overrule the previous case-as indeed it did on direct appeal. Barnette, 47 F. Supp. at 252-53; 319 U.S. at 642.

A similar case is Harris v. Younger, 281 F. Supp. 507 (C.D. Cal. 1968) (three-judge court), rev'd, 401 U.S. 37 (1971). There, the plaintiff challenged a state law that the Supreme Court had upheld in 1927 on First Amendment grounds. The three-judge district court held that later cases had effectively overruled the 1927 decision. 281 F. Supp. at 515-16. The Younger Court reversed on the ground that the lower court should have abstained in the case given that the issue could be resolved in ongoing state criminal litigation. Younger, 401 U.S. at 41-42.

Both Barnette and Younger involve "overruling," rather than merely "narrowing" from below, but both arguably illustrate how three-judge district courts might regard themselves as being able to take a more flexible view of precedent as compared to a single district judge. 
oral argument, or (2) summarily decide the case while stating explicitly that the order is not precedential to any degree besides binding the parties in that litigation.

There are strong arguments for a presumption that the Court should give plenary consideration to all direct appeals of three-judge district court decisions, absent exceptional circumstances. ${ }^{119}$ This process would entail full briefing and consideration, with some explanatory decision to follow. The result of this full briefing and consideration could be either a traditional full opinion or a shorter decision, much like Justice Brennan contemplated. ${ }^{120}$ A short decision could explain the main basis of the Court's decision or provide a case cite or two to signal what precedent dictated the outcome, thereby providing guidance for future three-judge district courts. The Court does not necessarily need to hold oral argument and two rounds of briefing in all such cases.

In fact, the Court used this approach, to some extent, in Benisek v. Lamone, the 2018 partisan gerrymandering case from Maryland, when it issued a five-page per curiam decision explaining the procedural basis for affirming the denial of a preliminary injunction. ${ }^{121}$ Instead of just summarily affirming the lower court's holding, the Court provided a brief rationale for its decision, which will help three-judge district courts in the future when they face a request for a preliminary injunction to invalidate a map for the next election. Thus, one way to solve the current confusion regarding the precedential value of the Court's summary dispositions is to adopt a presumption against summary dispositions. ${ }^{122}$

Alternatively, given the potential administrative concerns, the Court itself may not look kindly upon a directive to consider these cases in full, leading to our second suggestion: if the Court deems full hearings for all cases on appeal from three-judge district courts administratively impracticable, the Court should explicitly state that a summary disposition is not precedential and merely resolves the dispute before it. This practice would eliminate any concern that future courts or different litigants must rely upon the summary disposition, and it would

119. See supra Section II.B. One special circumstance would be the necessity for affirming by an equally divided vote. See, e.g., Common Cause v. Schmitt, 512 F. Supp. 489 (D.D.C. 1980) (three-judge court), aff' $d$ by an equally divided court, 455 U.S. 129 (1982); see also Justin Pidot, Tie Votes in the Supreme Court, 101 MinN. L. REV. 245, 266-68 (2016) (indicating that there were eighteen ties in reviewing appeals from three-judge district courts from 1925 through 2015).

120. See supra notes $107-08$.

121. 138 S. Ct. 1942 (2018) (per curiam); see also North Carolina v. Covington, 138 S. Ct. 2548 (2018) (per curiam) (providing several pages of explanation while summarily affirming in part and reversing in part).

122. As long ago as the 1920 s, the Court was explaining, albeit briefly, its rationale for a summary affirmance of an appeal from a three-judge district court. See, e.g., Donham v. West-Nelson Mfg. Co., 273 U.S. 657, 657 (1927) ("Affirmed on the authority of Adkins v. Children's Hospital, 261 U.S. 525 [(1923)]."); see also Felix Frankfurter \& James M. Landis, The Business of the Supreme Court at October Term, 1929, 44 HARV. L. REV. 1, 12 (1930) (suggesting that the Court "indicate briefly" the "character of considerations ... which govern its judgment"). There is no good reason why the present Court cannot similarly issue such short opinions. 
unshackle the Court from having to give full consideration to an issue that it may want to let percolate among the lower courts.

Chief Justice Roberts, in particular, may look more favorably upon our prescription that summary decisions should have no precedential weight and would likely recoil at a suggestion that the Court hear more of these cases in full. In a recent oral argument, the Chief Justice indirectly expressed concern about the prospect of an increased number of direct appeals from three-judge district courts. ${ }^{123} \mathrm{He}$ suggested that it is "a serious problem because there are a lot" of appeals in reapportionment cases from three-judge district courts. ${ }^{124}$ Ordinarily, he noted, the Court does not review all such cases but instead might allow an issue to "percolate" in the lower courts, but with an appeal from a three-judge district court, the Court is bound "to decide it on the merits." 125 In light of these remarks, Chief Justice Roberts presumably would oppose our proposal for the Court to devote greater attention to virtually all such appeals.

Although Chief Justice Roberts's concerns about spending more time on these cases are not trivial, they are ultimately unconvincing. His unease with a potential avalanche of direct appeals might have carried more weight in the 1960s and 1970s, when the Court was deciding twenty to thirty or even more direct appeals each Term in the midst of a workload of around 150 cases in total. ${ }^{126}$ Similar arguments about the Court's caseload convinced Congress to curtail the jurisdiction of three-judge district courts in $1976 .{ }^{127}$ This argument is much less convincing in the current era of a shrunken docket, where the Court hears around eighty cases each Term, with only a handful coming on direct mandatory appeal from three-judge district courts. ${ }^{128}$ To be sure, there are a significant-but not overwhelming - number of reapportionment cases brought every time states redraw their federal and state legislative districts after a new census in the early part of a

123. Transcript of Oral Argument at 38, Shapiro v. McManus, 136 S. Ct. 450 (2015) (No. 14-990). Justice Scalia wrote the opinion for a unanimous Court in Shapiro, which concerned the standard a district judge, to whom the case is initially assigned, should apply when determining whether to convene a three-judge district court under the relevant statute, 28 U.S.C. $\S \S 2284(a)$, (b). 136 S. Ct. at 453. The Court's opinion makes no reference to the policy concerns the Chief Justice raised during the oral argument, and the Chief Justice did not submit a separate opinion. Indeed, the opinion, somewhat counter to the Chief Justice's concerns, states: "Rare today, three-judge district courts were more common in the decades before 1976." Id. (emphasis added).

124. Transcript of Oral Argument at 38, Shapiro, 136 S. Ct. 450 (No. 14-990).

125. Id.

126. Solimine, supra note 55, at 138 (collecting data from the 1953 to 1993 Terms); see LEE EPSTEIN et Al., The Supreme Court Compendium: Data, Decisions, and Developments 88-90 (5th ed. 2012).

127. See supra notes 38-40 and accompanying text; see also Solimine, supra note 33, at 134-48 (describing the successful campaign to limit the three-judge district court).

128. For much of the 1960 s and 1970 s the Court was deciding up to 150 cases per Term. By the 1990s that number fell to its present rate of around seventy or eighty cases per Term. See EPSTEIN ET AL., supra note 126, at 88-90. See generally Ryan J. Owens \& David A. Simon, Explaining the Supreme Court's Shrinking Docket, 53 WM. \& MARY L. REV. 1219 (2012) (discussing the causes and consequences of this decline). 
decade. ${ }^{129}$ But not all of those cases result in a direct appeal to the Supreme Court, and of those that do, they often arrive at the Court spread out over several years. For example, in the 2016 Term the Supreme Court decided two cases that involved redistricting that occurred in 2011, after the 2010 census. ${ }^{130}$ The 2017 Term included the two partisan gerrymandering cases, Gill and Benisek, and a racial gerrymandering case, Abbott v. Perez. ${ }^{131}$ Plainly, the workload from direct appeals is not overly burdensome.

In addition, even while lamenting the mandatory nature of these direct appeals, the Justices themselves have noted that the caseload is not that large. In Abbott, the racial gerrymandering case from 2018, the Court held that it had jurisdiction over an appeal of an interlocutory injunction, noting that "appeals from such orders have not overwhelmed our docket." 132 Justice Alito wrote those words for the five-justice majority, which included Chief Justice Roberts, suggesting that the Chief has less concern about an increased caseload than he initially intimated. As the Court wrote, "[w]e appreciate our obligation to heed the limits of our jurisdiction, and we reiterate that $\S 1253$ [the statute providing for direct appeals from three-judge district courts] must be strictly construed. But it also must be sensibly construed ...."133 A sensible construction requires the Court either to consider these appeals fully or, if it is unwilling to do so, to refrain from issuing a one-line opinion without explanation that lower courts must follow as binding precedent.

Most importantly, Congress has made the policy decision to leave intact the three-judge district court, with its unusual direct appeal, for reapportionment and a small number of other cases. ${ }^{134}$ Keeping three-judge district courts for specific issues suggests that Congress wants the Court to continue hearing these disputes on direct appeal. Perhaps it was unwise to create such courts in the first instance, and maybe the conventional three-tiered path for all cases in federal court should cover reapportionment and other disputes now adjudicated before three-judge district courts. ${ }^{135}$ But it seems unlikely that, in today's political environment, Congress has the appetite to reform this aspect of federal court jurisdiction.

129. There are typically legal challenges to the reapportionment of federal or state legislative districts brought in most states after each decennial redistricting. See, e.g., Litigation in the 2010 Cycle, All AbOut Redistricting, http://redistricting.lls.edu/cases.php [https://perma.cc/7JS5-EXSV] (last visited Sept. 23, 2018).

130. See Bethune-Hill v. Va. State Bd. of Elections, 137 S. Ct. 788 (2017) (examining Virginia state legislative districts); Cooper v. Harris, 137 S. Ct. 1455 (2017) (examining North Carolina congressional districts).

131. Abbott v. Perez, 138 S. Ct. 2305 (2018); Benisek v. Lamone, 138 S. Ct. 1942 (2018) (per curiam); Gill v. Whitford, 138 S. Ct. 1916 (2018).

132. Abbott, 138 S. Ct. at 2323. The Court was specifically referring to a district court "enjoin[ing] the use of districting plans before moving on to the remedial phase," id., but we think its observation applies to all appeals from three-judge district courts in this context.

133. Id. at 2324. Justice Sotomayor, in dissent, lamented that, in accepting the appeal in that case, "our mandatory appellate docket will be flooded by unhappy litigants in three-judge district court cases, demanding our review." Id. at 2343 (Sotomayor, J., dissenting).

134. See supra notes $41-46$ and accompanying text.

135. Cf. Solimine, supra note 31, at 159-60 (concluding, after canvassing policy arguments in favor of and against three-judge district courts, that the latter arguments are more convincing). 
Either way, that is a policy choice the Court should respect by following the relevant statute and dealing with the direct appeals as actual appeals, not as substitutes for certiorari. ${ }^{136}$

Because of the inherent confusion in the Court's current practice, if it is unwilling to set these cases for full briefing and argument, with an explanatory opinion to follow, then as a next-best solution it should explicitly state in its summary opinions that the decisions carry no precedential weight and bind only the parties to the specific litigation. This practice would at least eliminate one confusing aspect of the current approach. A qualifying statement from the Court instructing lawyers and lower courts that they should not treat a summary affirmance as binding precedent would be similar to an "unpublished" opinion that a lower court may issue in a case that the court finds less worthy of publication. Although parties may cite unpublished opinions as persuasive authority, a district court need not treat a circuit court's unpublished decision as binding precedent. ${ }^{137}$ Allowing courts to designate certain opinions as "unpublished" and therefore not precedential arguably eases the court's workload, allowing it to issue a perhaps less-thanpolished opinion that resolves the dispute without worrying about the future precedential effects of that specific case. ${ }^{138}$ Whether that feature of appellate court practice actually helps judicial administration is perhaps debatable, ${ }^{139}$ but

136. Given that, as we have been emphasizing, the relevant statutory language explicitly refers to an "appeal to the Supreme Court," 28 U.S.C. $\$ 1253$ (2012), it might be argued that our second suggestion, permitting the Court to summarily rule but not to accord such ruling precedential weight, is in tension with the statutory language. The argument would be that such a diluted ruling is not what Congress contemplated when it referred to an "appeal" available for three-judge district courts. We disagree because there are examples of explained decisions on appeals that do not have precedential weight. Consider the common practice of not giving such weight to decisions of the U.S. Courts of Appeals that are not officially published. See infra note 138 and accompanying text. We concede that the analogy to officially unpublished decisions of the Courts of Appeals is not perfect. Any decision of the Supreme Court with even minimal explanation is likely to be considered of some significance. Nonetheless, the long-standing experience of the Courts of Appeals on this issue is worthy of the Supreme Court's consideration.

137. See, e.g., 5TH CIR. R. 47.5.4 (“Unpublished opinions issued on or after January 1, 1996, are not precedent, except under the doctrine of res judicata, collateral estoppel or law of the case (or similarly to show double jeopardy, notice, sanctionable conduct, entitlement to attorney's fees, or the like)."); Anne Coyle, A Modest Reform: The New Rule 32.1 Permitting Citation to Unpublished Opinions in the Federal Courts of Appeals, 72 FordHAM L. REv. 2471, 2472-74, 2489-90 (2004) (surveying federal circuit rules on citation and precedential effect of unpublished opinions); Martha Dragich Pearson, Citation of Unpublished Opinions as Precedent, 55 HASTINGS L.J. 1235, 1235-36 \& nn.7-11 (2004) (surveying federal circuit rules negating or restricting precedential effect of unpublished opinions).

138. See, e.g., Jeffrey O. Cooper, Citability and the Nature of Precedent in the Courts of Appeals: A Response to Dean Robel, 35 IND. L. REV. 423, 429 n.37 (2002) ("One of the most commonly-voiced rationales for unpublished opinions is that they free judges of the burden of producing polished, thoroughly-reasoned text."); Jeffrey O. Cooper \& Douglas A. Berman, Passive Virtues and Casual Vices in the Federal Courts of Appeals, 66 BROOK. L. REV. 685, 703 (2001) (explaining courts' rationale for issuing an unpublished opinion as "the notion that, where a case is easily resolved on the basis of existing law, there is no need for the court to take the time to write a polished, published opinion because the case adds nothing new to the body of law, and there is no need for anyone to cite the court's decision because other precedent exists to establish the pertinent point").

139. See, e.g., Kenneth F. Hunt, Note, Saving Time or Killing Time: How the Use of Unpublished Opinions Accelerates the Drain on Federal Judicial Resources, 61 SYRACUSE L. REV. 315, 332 (2011) 
the efficacy of using unpublished opinions is irrelevant to our current inquiry. Instead, the important takeaway is that the federal judiciary already has a mechanism to resolve a case without creating binding precedent, so the Court is well within the bounds of established judicial practice to adopt this method for the few cases it receives on direct appeal.

Sound jurisprudential and institutional reasons support a presumption that the Court should hear all of these cases and issue an explanatory opinion in each one. But we are also realistic in acknowledging that the Court may not adopt this solution. In the alternative, the Court could cure at least one aspect of the current confusion by stating explicitly that summary dispositions of appeals from threejudge district courts are not actually precedential. That practice would represent a significant improvement over the current status quo. ${ }^{140}$

\section{REFORMING THE COURT'S NARROW CANON OF CONSTRUCTION OF THE} THREE-JUDGE COURT ACT

A corollary of our proposal should lead the Court to jettison its canon of strict and narrow construction of the three-judge district court statute. Currently, the Court applies a strict construction to almost all jurisdictional statutes, which often leads the Court to overtly or inferentially limit the number of cases that flow to the Court and the lower federal courts. ${ }^{141}$ Similarly, when construing the statute dealing with the three-judge district court, the Court has frequently engaged in an overt strict construction to reduce the number of times a three-judge district court needs to be convened and to limit direct appeals to the Court. ${ }^{142}$ Even when conferring jurisdiction over an appeal from an interlocutory injunction-where the Court read the three-judge district court's decision broadly as issuing an injunction even though the lower court did not use that word - the Court still said that it must "strictly construe" the statute. ${ }^{143}$ The Court might invoke this same narrow construction to justify the use of summary dispositions that may or may not be precedential. $^{144}$

But the Supreme Court has recently eschewed application of this narrow canon for jurisdictional statutes. ${ }^{145}$ In Shapiro v. McManus, the Court, in a unanimous

(arguing that the system of unpublished opinions creates uncertainty for "consumers" of opinions and increases the amount of federal litigation).

140. We acknowledge that under our proposal, summary affirmances without any precedential value may increase uncertainty in the lower courts regarding the proper disposition of reapportionment litigation, and may create more litigation and appeals to the Supreme Court. All of this is possible, but there is already substantial uncertainty under the present regime regarding how lower courts, and the Court itself, should interpret summary affirmances. On balance, we think it would clarify matters to strip those affirmances of any precedential value. It would also incentivize the Court to issue explanatory opinions to have a precedential effect.

141. For an overview of this canon, see generally Aaron-Andrew P. Bruhl, The Jurisdiction Canon, 70 VAnd. L. REV. 499 (2017). Professor Bruhl does not expressly discuss the application of this canon to the three-judge district court context.

142. See Solimine, supra note 33, at 134-35.

143. Abbott v. Perez, 138 S. Ct. 2305, 2324 (2018).

144. See supra notes $117-18$ and accompanying text.

145. See Bruhl, supra note 141, at 521-25. 
opinion by Justice Scalia (a noted textualist), studiously applied strict textual analysis to conclude that the jurisdictional statutes require the convening of the three-judge district court when a constitutional challenge to a reapportionment presents a substantial federal question. ${ }^{146}$ There was no mention of the strict interpretation canon. Similarly, in Abbott, the Court recently conferred jurisdiction over an appeal from what it deemed to be an interlocutory injunction, even though the lower court explicitly disavowed that its opinion was an injunction. ${ }^{147}$ The Court reiterated that it must construe the statute strictly while also explaining that it should apply a "sensible" construction to hear the case. ${ }^{148}$ Justice Sotomayor, in dissent, chastised the majority for abandoning a strict interpretation, which she said would result in more direct appeals. ${ }^{149}$

Professor Aaron-Andrew Bruhl has argued persuasively that the legal system should evaluate the narrow construction canon (like other statutory construction canons) based on, among other things, its historical pedigree, as well as its relationship to constitutional values and congressional preferences. ${ }^{150}$ Applying these factors, the strict construction canon does not fare well in the present context. Strict construction certainly has historical pedigree; the Supreme Court overtly invoked a narrow construction of the three-judge district court statute as far back as $1928 .{ }^{151}$ But under the other factors, the narrow construction canon has no place when considering the three-judge district court statute. These courts hear contentious constitutional issues that underlie the foundation of our democracy, which Congress determined will benefit from a special tribunal. A strict construction of the jurisdictional statutes to limit the Court's docket for these cases runs counter to this legislative judgment. Thus, the Court's shrunken docket overall, congressional amendments in the 1970s, and the institutional characteristics of the modern three-judge district court—when considered together-demonstrate that the Court should not interpret the statute to limit its own jurisdiction over direct appeals.

Minimizing summary dispositions in either direction-by hearing all of these cases or stating explicitly that they are not precedential-will not unduly burden the Court. The continued use of such dispositions is particularly indefensible in an era of a shrunken docket, where the Court hears around eighty cases a year and only a few of those involve direct appeals from three-judge district courts. ${ }^{152} \mathrm{~A}$

146. 136 S. Ct. 450, 454-56 (2015).

147. Abbott v. Perez, 138 S. Ct. 2305, 2319 (2018).

148. See id. at 2324.

149. Id. at 2343 (Sotomayor, J., dissenting).

150. See Bruhl, supra note 141, at 503.

151. See Ex parte Collins, 277 U.S. 565, 567-69 (1928) (Brandeis, J.). See generally Solimine, supra note 33, at 134-35. Not coincidentally, the Court's practice of summary dispositions of direct appeals goes back this far as well. See also Frankfurter \& Landis, supra note 122, at 8-11 (discussing frequent use of summary disposition of direct appeals in the 1927 and 1928 Terms).

152. See Owens \& Simon, supra note 128, at 1225; cf. Tara Leigh Grove, The Structural Case for Vertical Maximalism, 95 CoRNELl L. REV. 1, 4 (2009) (noting that the Court should "make the most of the cases it does hear by issuing broad (maximal) decisions that guide the lower courts in the many cases that it lacks the capacity to review"). 
presumption in favor of explanatory opinions, even relatively short ones, should appropriately discipline the Court to give more serious attention to the statutes that vest mandatory appeals with the Court, instead of treating them the same as petitions for certiorari but with differing precedential effects for a refusal to hear a case. ${ }^{153}$ The Court should limit its one-line orders to those cases, like denials of certiorari, where it truly intends to leave the lower court's opinion intact without any explanation or precedent.

\section{Precedent That Binds Three-Judge District Courts}

A related question of precedent vexes three-judge district courts themselves: to what extent must they follow prior cases of the circuit court in which they sit? On the one hand, these courts are formally "district" courts, suggesting that they should follow the caselaw of the circuit, like all single district judges in that circuit. This appears to be the majority view among these courts. ${ }^{154}$

On the other hand, an appeal from a decision of these courts goes directly to the Supreme Court, skipping the circuit court of appeals altogether. ${ }^{155}$ If a court is bound only by the decisions of the courts that review them, then the only precedent that should bind three-judge district courts are decisions of the Supreme Court. Even though three-judge district courts are called "district" courts, they are not inferior to the circuit courts in all circumstances. Three-judge district courts are specialized creatures that are not formally "below" the circuit courts but instead generally operate outside of them. Moreover, Congress created these courts to have greater independence to promote their legitimacy. Under this view, circuit precedent should not bind them. ${ }^{156}$

\section{A. CURRENT VIEWS ON WHETHER CIRCUIT PRECEDENT SHOULD BIND THREE-JUDGE DISTRICT COURTS}

Three-judge district courts have struggled with whether they must follow circuit precedent. Some judges have determined that, because they are technically sitting on "district" courts, and because district courts are below the circuit courts of appeal, then circuit precedent must bind them. But other judges sitting on three-judge district courts take the opposite view: circuit precedent is persuasive, but not binding, given that circuit courts cannot review their decisions, as an appeal skips the court of appeals and goes directly to the Supreme Court. Few judges, however, have considered explicitly the rationale behind either approach.

153. Several commentators have characterized the Court's conflation of denials of certiorari with summary affirmances of mandatory appeals as "lawless" because it is arguably inconsistent with the direct appeal statutes and is done, it appears, mainly for the Court's own convenience. See, e.g., Edward A. Hartnett, Questioning Certiorari: Some Reflections Seventy-Five Years After the Judges' Bill, 100 Colum. L. ReV. 1643, 1708-10 (2000).

154. See infra note 168 and accompanying text.

155. See 28 U.S.C. $\S 1253$ (2012).

156. As we discuss below, under this model three-judge district courts still could find circuit precedent highly persuasive, even if not binding. 
The analysis from a three-judge district court that reviewed Ohio's post-2000 redistricting plan exemplifies this problem. In Parker $v$. Ohio, the plaintiffs alleged that the redistricting plan for the state legislature diluted the votes of African-Americans, in violation of the Voting Rights Act. ${ }^{157}$ Because the claim challenged a statewide redistricting, it went before a three-judge district court. The plaintiffs sought the creation of "influence districts" as a remedy to give African-Americans greater voting power. ${ }^{158}$ In an influence district, even though minorities "cannot form a majority, ... they are sufficiently large and cohesive to effectively influence elections, getting their candidate of choice elected." ${ }^{159}$ In a prior case, Cousin v. Sundquist, the Sixth Circuit held that the Voting Rights Act did not support a claim for influence districts. ${ }^{160}$ Cousin did not go before a threejudge district court because the claim in that case was about the method of electing judges in a county in Tennessee ${ }^{161}$ —not a congressional or statewide legislative redistricting claim that would fall under the Three-Judge Court Act. Yet the substantive nature of the issue was the same: may plaintiffs secure the creation of influence districts under the Voting Rights Act?

The three-judge district court in Parker determined that it was required to follow the Sixth Circuit's holding in Cousin that the VRA did not support this argument: "While plaintiffs are correct that the . . Supreme Court [has] not yet ruled on influence districts, we are bound by precedent in this circuit."162 In other words, the Parker court found that, because of Cousin, "influence claims are not cognizable in our circuit." ${ }^{163}$ Yet the court provided no reasoning for its conclusion that it must follow Sixth Circuit precedent. The majority opinion simply stated, without explanation, "we are bound by precedent in this circuit," 164 and the concurrence said, again without any animating logic, "a majority of three-judge district courts and circuit courts of appeals hold that circuit court precedent is binding on a three-judge district court."165 It is unclear how the court would have ruled on the issue had it exercised its own, independent judgment, though one concurring judge said he would have rejected the claim even without the precedent he found binding ${ }^{166}$ and the other judge, concurring for a different reason, stated that he would recognize a claim for influence districts. ${ }^{167}$

157. 263 F. Supp. 2d 1100, 1102-03 (S.D. Ohio 2003) (three-judge court).

158. Id. at 1104 .

159. Id.

160. 145 F.3d 818,828 (6th Cir. 1998).

161. Id. at 820 .

162. Parker, 263 F. Supp. 2d at 1105.

163. $I d$.

164. $I d$.

165. Id. at 1108 (Graham, J., concurring).

166. $I d$.

167. Id. at 1113 (Gwin, J., concurring). 
Most three-judge district courts have agreed with the Parker court, finding that circuit precedent binds them. ${ }^{168}$ One three-judge district court provided some logic for this rule: "The addition by Congress in the three-judge court acts of a second district judge and a Circuit Judge together with direct appeal to the Supreme Court was not a grant of authority with elevated precedential stature but a withdrawal of power from a single judge."169 According to this view, a threejudge district court is simply that - a district court— that sits within the circuit. The court itself is called the "District Court of" the particular state in the circuit. ${ }^{170}$ It is not constituted as a geography-free federal tribunal.

Failing to adhere to circuit precedent could create a practical problem: the creation of "intra-circuit conflict with no meaningful mechanism for its resolution within the Circuit," meaning that only the Supreme Court could resolve that conflict. ${ }^{171}$ That is, if a three-judge district court rules contrary to the prior decisions of a previous three-judge district court or the circuit itself, then the circuit courteither through a normal appellate panel or en banc review-has no mechanism to reconcile the conflicting rules. This intra-circuit conflict could lead to confusion and additional litigation, forcing the Supreme Court to step in and resolve the discrepancy.

Yet the alternative view, that circuit precedent does not formally bind the three-judge district court, is quite persuasive, at least from the perspective of traditional judicial decisionmaking. As Judge Gwin, who wrote separately in Parker, explained:

The doctrine of stare decisis in practice, commands that lower courts follow the precedent of courts who review their decisions. If our decision is reviewable only by the Supreme Court, logic suggests that we are not bound by circuit authority. While such authority may persuade, only Supreme Court

168. See, e.g., Ga. State Conference of NAACP v. Georgia, 269 F. Supp. 3d 1266, 1278 (N.D. Ga. 2017) (three-judge court) (stating that "we are bound by Eleventh Circuit precedent); Perez v. Abbott, 250 F. Supp. 3d 123, 138-39 (W.D. Tex. 2017) (three-judge court) (stating that the court must "follow [binding circuit precedent] in the absence of any authority to the contrary"); Ala. Legislative Black Caucus v. Alabama, 988 F. Supp. 2d 1285, 1305 (M.D. Ala. 2013) (three-judge court) (stating that the court "is bound by Eleventh Circuit precedent"); NAACP v. Snyder, 879 F. Supp. 2d 662, 672 (E.D. Mich. 2012) (three-judge court) (stating that Sixth Circuit precedent "is binding precedent that controls our decision today"). For a lengthier list of cases taking this position, see Baksalary v. Smith, 579 F. Supp. 218, 226-27 n.13 (E.D. Pa. 1984) (three-judge court).

169. Russell v. Hathaway, 423 F. Supp. 833, 835 (N.D. Tex. 1976) (three-judge court).

170. See Remick Music Corp. v. Interstate Hotel Corp. of Neb., 58 F. Supp. 523, 542 (D. Neb. 1944) ("However constituted, the [three-judge district] court . . . was only the District Court for the Federal Judicial District of Nebraska."). A practical analysis would emphasize how the circuit is intertwined with the creation and life of the three-judge district court. One could imagine convening the court and selecting the three judges in other ways, such as by lottery, or by the Chief Justice of the United States. But Congress designated the head of the circuit to do it, and the statute seems to contemplate, though does not explicitly require, that all of the appointed judges be from that circuit. Likewise, one could imagine a geography-free court (such as the U.S. Tax Court), but Congress declined to pursue this option as well. All proceedings of the court take place, literally, in one circuit.

171. Russell, 423 F. Supp. at 835. 
holdings would seem to have controlling authority. ${ }^{172}$

Similarly, a three-judge district court in Washington State explicitly stated, "[i]n this special three-judge court case we are not bound by any judicial decisions other than those of the United States Supreme Court." ${ }^{173}$ Other courts have at least considered it an open question as to whether they must follow circuit precedent or whether only Supreme Court caselaw can bind them. ${ }^{174}$

\section{B. SIGNIFICANCE OF DETERMINING WHICH PRECEDENT APPLIES}

At the outset, the question of whether three-judge district courts must follow circuit precedent as binding law might seem trivial. Whether circuit law is binding precedent or merely persuasive may not make a difference in most cases, as the three-judge district court is likely to follow a well-reasoned circuit court decision regardless of whether it is formally binding precedent or not. In the grand scheme of things, what is the big deal?

There are three primary reasons for three-judge district courts to consider carefully whether they must follow circuit precedent: (1) the formal aspects of proper judicial decisionmaking, (2) adherence to congressional intent in achieving greater independence and legitimacy, and (3) the desire to reach correct outcomes, especially in politically charged cases.

First, it is improper as a matter of judicial hierarchy for a case to bind a subsequent court when the court issuing that purported precedent cannot review the subsequent court's decisions. "Binding precedent" has a specific meaning: a "lower" court must follow the decisions of a "higher" court in the judicial hierarchy. ${ }^{175}$ This is a consideration grounded in formalism, or the notion that judicial decisionmaking must adhere to formal legal rules. ${ }^{176}$ A circuit court cannot review the decision of a three-judge district court, so a three-judge district court

172. Parker, 263 F. Supp. 2d at 1112 n.3 (Gwin, J., concurring).

173. Jehovah's Witnesses in Wash. v. King Cty. Hosp., 278 F. Supp. 488, 504-05 (W.D. Wash. 1967) (three-judge court), aff' d, 390 U.S. 598 (1968).

174. See, e.g., Ala. Legislative Black Caucus v. Alabama, 988 F. Supp. 2d 1285, 1342 n.13 (M.D. Ala. 2013) (three-judge court) (Thompson, J., concurring and dissenting); Confederated Tribes of Colville Indian Reservation v. Washington, 446 F. Supp. 1339, 1356 n.16 (E.D. Wash. 1978) (threejudge court); Poe v. Werner, 386 F. Supp. 1014, 1016-17 \& n.4 (M.D. Pa. 1974) (noting "a difference of opinion among the federal courts on this question"); see also Ga. State Conference of NAACP v. Georgia, 269 F. Supp. 3d 1266, 1286 (N.D. Ga. 2017) (Duffey, J., concurring) (asserting that the Jehovah's Witnesses decision, 278 F. Supp. at 504-05, is the only one where a court "concluded it was not bound by its circuit's precedent"). After we posted a draft of this article online, another three-judge district court—citing our draft-noted that " $[t]$ here is some question as to whether the precedent of the circuit in which a three-judge district court sits is binding on that court." Lavergne v. U.S. House of Representatives, No. 17-793, 2018 WL 4286404, at*8 n.3 (D.D.C. Sept. 6, 2018) (three-judge court), appeal dismissed for lack of jurisdiction, 2018 WL 4257881 (U.S. Nov. 5, 2018) (No. 18-290). The court declined to "weigh in on this debate" but said that even if D.C. Circuit precedent was not binding, it was "highly persuasive." Id.

175. See Caminker, supra note 21 , at 818.

176. See, e.g., Frederick Schauer, Formalism, 97 YALE L.J. 509, 510 (1988) (footnotes omitted) (“At the heart of the word 'formalism,' in many of its numerous uses, lies the concept of decisionmaking according to rule."). 
need not, as a matter of formal judicial decisionmaking, adhere to circuit precedent. Of course, a three-judge district court can follow circuit precedent as persuasive if it wants; the proper understanding of a judge's role in a hierarchical system, however, does not require it to do so. ${ }^{177}$

Three-judge district courts themselves express confusion over whether they must follow circuit precedent as a matter of proper judicial decisionmaking. As a three-judge district court in Georgia recently explained,

[S]ome say the traditional rationale for stare decisis-following the precedent of courts that review the lower court's decisions-does not make sense for three-judge district courts like ours. . . . Nevertheless, this panel elects to follow Eleventh Circuit precedent.

At the same time, we realize that what we decide here cannot be reviewed by the Eleventh Circuit sitting en banc, even if the en banc court were to disagree with us. And our lack of guidance extends beyond the en banc court, because the Supreme Court routinely issues summary affirmances of threejudge district courts in voting cases. Those summary opinions often tell us nothing more than that a judgment was correct "but not necessarily the reasoning." Thus, in this area of voting rights, we are left to fill in gaps where we have little or incomplete guidance from the courts that may ultimately resolve these issues. ${ }^{178}$

One of the judges, in a concurring opinion, lamented that "[i]t seems the rationale for following circuit precedent is because courts have found that some law is better than no law." 179 Noting that the question was "unclear," the judge "reluctantly" agreed to follow circuit precedent because doing so in that case "promotes, albeit to an uncertain degree, uniformity of the law at least within a circuit." 180

As this recent Georgia case demonstrates, some judges on three-judge district courts find the notion odd, if not improper, that they must follow circuit law when the circuit court cannot overrule them. A proper application of judicial hierarchy in this instance would resolve the confusion.

Second, Congress presumed that having three judges at the outset of a case would better protect important rights such as the right to vote. ${ }^{181}$ Independence in these important political cases is thus a significant virtue underlying the very existence of three-judge district courts. Congress created the three-judge district court

177. As discussed below, as a matter of court rule, circuit court precedent can bind a subsequent circuit court panel, even though one panel cannot review the decisions of another panel. Yet the same court, sitting en banc, can reverse a panel decision. More poignantly, the prior-panel rule rests on strong institutional reasons, such as the need for uniformity within a circuit, that are less relevant in the threejudge district court context. See infra notes 211-17 and accompanying text.

178. Ga. State Conference of NAACP, 269 F. Supp. 3d at 1278-79 n.7 (quoting Mandel v. Bradley, 432 U.S. 173 (1977) (per curiam)).

179. Id. at 1286 (Duffey, J., concurring).

180. Id. at $1286-87$.

181. See supra note 45 (discussing the legislative history). 
specifically to allow multiple minds to resolve highly charged issues at the case's inception. ${ }^{182}$ Although it is not clear why Congress kept the three-judge district court for redistricting and campaign finance cases while abolishing it in most other instances in 1976, it seems that an animating rationale was that three judges at the outset are superior for cases involving the political process. ${ }^{183}$ Having three judges can lead to greater deliberation and reduce the likelihood that pure partisanship will drive the decisions at the trial court level. ${ }^{184}$

A rule that three-judge district courts must follow circuit precedent, however, may harm the unique status, and thus legitimacy, that Congress sought in their creation. Three-judge district courts would be without the authority to determine independently whether the circuit rule in a similar case is wise or even correct; a mandatory rule would obligate them to follow the circuit precedent blindlyeven precedent that they find simply wrong but that the en banc court has not yet overturned. In this way, a rule that three-judge district courts must invariably follow circuit precedent would unnecessarily tie the hands of the three-judge district court. Congress, in creating this unique species of the judiciary to resolve certain

182. Henry J. Friendly, Indiscretion About Discretion, 31 EMORY L.J. 747, 757 (1982) (“Assuming that all panel members take seriously their responsibility for independent exercise of judgment, the give and take of discussion may produce a result better than any single mind could reach.").

183. See Solimine, supra note 33, at 142 ("The legislative record is unclear regarding the motivation for the amendment [abolishing three-judge district courts in general but retaining them for redistricting cases], but such luminaries as Judges Henry Friendly and J. Skelly Wright enthusiastically endorsed it in their testimony. They pointed out the various burdens associated with convening such courts and argued that the purported need for the court had come and gone. On the other hand, they suggested that it was appropriate to convene such courts for redistricting cases in order to facilitate issues of 'public importance' and, in their view, the 'public acceptance' of decisions. Moreover, they stated that the evidence in such cases was likely to be heavily statistical in nature, and that no additional taking of other evidence would typically be necessary." (citing Admiralty Jurisdiction, United States As a Party, General Federal Question Jurisdiction, Three-Judge Courts: Hearing on S. 1876 Before the Subcomm. on Improvements in Judicial Mach. of the S. Comm. on the Judiciary, 92d Cong. 748-50, 757-61, 78392 (1972) (statements of Judge Friendly and Judge Wright)).

184. See Douglas, supra note 16, at 462-63. The record is unclear as to both why Congress left the three-judge district court intact in 1976 for reapportionment cases and whether and to what extent members of Congress perceived that judges in such cases voted in ideologically predictable ways. For a contemporaneous account addressing this point by the Deputy Counsel to the Senate Judiciary Committee, see Michael J. Mullen, Improving Judicial Administration by Repealing the Requirements for Three-Judge District Courts, 20 CATH. LAw. 372, 376 (1974) ("The judgment was that there is a great deal of leeway given to a court in a reapportionment case, and the appearance of fairness and fairness in fact must be assured. A decision by a single judge-a Republican judge or a Democratic judge - that might be questioned as politically motivated should be avoided.”). That said, we are not arguing that in 1976-or today-federal judges serving on three-judge district courts were systematically less ideological than their peers who decided similar cases (such as those concerning elections) sitting alone. See, e.g., Adam B. Cox \& Thomas J. Miles, Judicial Ideology and the Transformation of Voting Rights Jurisprudence, 75 U. CHI. L. REV. 1493 (2008) (finding that ideology has a "sizable and robust effect on the likelihood of a judge" assigning liability in VRA section 2 cases); Mark Jonathan McKenzie, The Influence of Partisanship, Ideology, and the Law on Redistricting Decisions in the Federal Courts, 65 PoL. RES. Q. 799 (2012) (finding that judges in redistricting cases can be described as constrained partisans). Our point is that it is reasonable to infer that Congress retained the three-judge district court for reapportionment cases, at least in part, on the presumption that ideological and political considerations by judges in these settings would be ameliorated, or at least balanced, with multiple members. 
issues, believed that it would be better for three judicial minds to grapple with potentially difficult and controversial topics at the trial court level. ${ }^{185}$ That special process within the federal court system provides the legitimacy that undergirds these courts' creation. Although all lower courts must follow precedent, unnecessarily binding three-judge district courts would take away an aspect of their independence.

Finally, forcing a three-judge district court to follow circuit precedent might lead this court to come to a contrary conclusion than if it had reviewed the matter anew, producing results that could undermine the democratic process. One aspect of the independence and legitimacy that three-judge district courts enjoy is the increased likelihood that their collective wisdom might help them reach the "correct" decision and that a single judge's ideology will not rule the day. The hope for greater accuracy is a virtue of three-judge district courts. ${ }^{186}$ If the three-judge district court finds that circuit precedent is wrong, however, there is no way for the court to avoid that decision under a rule directing it to follow circuit precedent as binding. Of course, three-judge panels of a circuit court of appeals also have multiple members, possibly tempering ideological and incorrect decisions, so one might think that it is inconsequential to have those decisions bind subsequent three-judge district courts. But Congress designated certain cases involving the political process for three judges at the trial level to give these courts greater legitimacy; tying their hands might take away from that goal.

Under a regime that requires three-judge district courts to follow circuit precedent they find misguided, the judges would have to highlight the problem and hope that the Supreme Court will correct the error on direct review. Yet the Court often summarily affirms these courts' decisions. ${ }^{187}$ That fact means that the Court could affirm the three-judge district court's decision, albeit on a different ground, without passing upon the circuit precedent on which the three-judge district court relied. This course of events could, in turn, cause the Court itself to perpetuate a circuit split on an issue. Suppose that two different circuits have ruled differently on a legal issue involving a local redistricting, but the Supreme Court has not yet resolved the conflict. Three-judge district courts encountering the same legal issue in a statewide redistricting case in those circuits would have to follow each circuit's law. That is, the three-judge district courts would be required to perpetuate that circuit split. And because these cases receive direct appeal to the Supreme Court, the Court could summarily affirm both cases without explanation, with the perverse effect of the Court inadvertently sustaining a circuit split. It would be unclear whether the Court, in summarily affirming the cases, was also affirming the three-judge district court's reliance on circuit precedent. Allowing a three-judge district court to consider the issue independently could mitigate this

185. Douglas, supra note 16, at 462-63.

186. See id:; cf. Dan T. Coenen, To Defer or Not to Defer: A Study of Federal Circuit Court Deference to District Court Rulings on State Law, 73 MinN. L. REV. 899, 924 (1989) (“Assigning several judges to a problem reduces the risk that important lines of analysis will escape attention.”).

187. See supra Section II.B. 
problem by permitting three-judge district courts to resolve cases as they see fit, avoiding the potential of an incorrect decision (as deemed later by the Supreme Court) simply because the lower court could not question circuit precedent.

In fact, the Supreme Court has inadvertently perpetuated an implicit circuit split on whether circuit precedent is binding by affirming three-judge district courts that have both followed and not followed circuit precedent. Does this mean that circuit precedent both binds and does not bind a three-judge district court? For example, the Court has summarily affirmed three-judge district courts that followed circuit precedent, ${ }^{188}$ but it also summarily affirmed a decision in which the three-judge district court explicitly stated that circuit precedent did not bind it. ${ }^{189}$ By summarily affirming in both instances, the Court at least signaled that both approaches are correct, though without a written opinion it is difficult to know for sure. Three-judge district courts, as well as the litigants before them, are left lost at sea on this important question, which could dictate the outcome of cases involving the core aspects of our democracy.

In sum, although there is certainly a formalistic aspect to our proposal, in that courts generally should not feel bound by other courts that cannot review them, prudential and institutional considerations are also significant. At its core, tying the hands of three-judge district courts may increase the likelihood that these courts will reach decisions that fail to consider the substantive issues independently. This process could lead to results that the Supreme Court ultimately may find to be incorrect, yet the decision will affect upcoming elections in the meantime. In addition, the Supreme Court has obliquely affirmed both approachesapproving of decisions both where three-judge district courts have followed and not followed circuit precedent-creating doctrinal confusion in the process. Perhaps most importantly, Congress wanted three-judge district courts, to a degree, to exhibit independence and achieve more "legitimate" decisions for certain important cases by having multiple judges hear them from the outset. Unnecessarily binding these courts to circuit precedent runs contrary to that goal.

\section{THREE-JUDGE DISTRICT COURTS AND THE HIERARCHY OF FEDERAL COURTS}

To determine whether three-judge district courts must follow circuit caselaw, we must assess the relationship between trial and appellate courts in light of the goals behind the Three-Judge Court Act. As Professor Evan Caminker explains, in a system founded upon hierarchical precedent, "longstanding doctrine dictates that a court is always bound to follow a precedent established by a court 'superior' to it."

188. See, e.g., Cox v. Larios, 542 U.S. 947 (2004), aff'g 300 F. Supp. 2d 1320, 1352 n.16 (N.D. Ga.) (per curiam) (three-judge court).

189. Jehovah's Witnesses in Wash. v. King Cty. Hosp., 390 U.S. 598 (1968), aff' g 278 F. Supp. 488, 504-05 (W.D. Wash. 1967) (per curiam) (three-judge court).

190. Caminker, supra note 21, at 818; see also Evan H. Caminker, Precedent and Prediction: The Forward-Looking Aspects of Inferior Court Decisionmaking, 73 TEX. L. REV. 1, 12 (1994) ("It is axiomatic that an inferior court must respect prior precedents created by its superior courts . . .."); see also id. at 3 ("[A]n inferior court must follow precedent established by a court that is superior to it."). 
supervisory power over the lower court, such that the lower court must conform its decision to the superior court's precedent. As Professor Caminker explains:

The duty to obey hierarchical precedent tracks the path of review followed by a particular case as it moves up the three federal judicial tiers: A court must follow the precedents established by the court(s) directly above it. District courts must follow both Supreme Court decisions and those issued by whichever court of appeals has revisory jurisdiction over its decisions, and courts of appeals must heed Supreme Court decisions. However, a court can ignore precedents established by other courts so long as they lack revisory jurisdiction over it. Thus, a circuit court of appeals is not bound by decisions of coordinate circuit courts of appeals, and a district court judge may ignore the decisions of "foreign" courts of appeals as well as other district court judges, even within the same district. ${ }^{191}$

Despite the universal acceptance of this system of judicial hierarchy, Professor Caminker persuasively argues that the doctrine, broadly applied, is not required as a matter of constitutional law. ${ }^{192}$ Article III, creating one Supreme Court, strongly implies that all federal courts must follow Supreme Court precedent. ${ }^{193}$ But the Constitution is less clear on whether and when lower federal courts must follow other lower federal courts. Article III, he points out, is opaque on hierarchy as such; it does not mandate the creation of the lower federal courts, and it suggests that Congress has considerable authority to regulate and limit the jurisdiction of the Supreme Court and of the lower courts it does create. ${ }^{194}$ The doctrine, Caminker continues, is better thought of as primarily resting on a set of consequentialist and institutional (prudential) concerns, including judicial economy, deference to the presumably more proficient reasoning of multimember appellate courts accustomed to law development, and the need for uniform interpretation of the law. ${ }^{195}$ Despite these somewhat shaky jurisprudential foundations, Caminker acknowledges that the "overwhelming consensus" of both judges and academics supports the "precedent model," under which "lower courts ought to define the law merely by interpreting existing precedents, without considering what their higher courts would likely do on appeal." 196

Assuming the validity of the rule - that "higher" courts bind lower court judges in the judicial hierarchy-then the converse will usually be true as well: absent a particular justification, judges need not follow decisions of courts that are not

191. Caminker, supra note 21 , at $824-25$ (footnotes omitted).

192. Id. at 828-38.

193. U.S. ConST. art. III, $\S 1$; Caminker, supra note 21 , at 834.

194. Caminker, supra note 21, at 828-38.

195. Id. at 839-56.

196. Caminker, supra note 190, at 5-6; see also Grove, supra note 152, at 31-32 (discussing and summarizing literature on the constitutional significance of hierarchal precedent); Pauline T. Kim, Lower Court Discretion, 82 N.Y.U. L. REV. 383, 409-10 (2007) (highlighting the difference between a lower court's duty to adhere to formal precedent and a lower court's discretion not to follow a superior court's preferences). 
directly above them. Indeed, this is the reason for why one district court need not follow the ruling of a prior district court and why one circuit court is not required to rule consistently with another circuit court. ${ }^{197}$

This brings us to the ultimate question: is a three-judge district court inferior to a circuit court? From a formal hierarchical standpoint, the answer is no. In the federal court hierarchy, the only court that sits "above" the three-judge district court is the Supreme Court. Only the Supreme Court can hear an appeal from and affirm or reverse the three-judge district court's ruling. ${ }^{198}$ The circuit court plays no role in the three-judge district court's operation beyond having the Chief Judge of the circuit appoint two of the judges and having at least one circuit judge serve on the panel. ${ }^{199}$ Congress, the creator of three-judge district courts, gave the circuit court no other function with respect to these special tribunals. Once the ministerial responsibilities of convening the court are over, the circuit court plays no further role in the operation of the three-judge district court. ${ }^{200}$ If a court must

197. Caminker, supra note 21, at 824-25.

198. 28 U.S.C. $\$ 1253$ (2012).

199. 28 U.S.C. $\$ 2284$ (b)(1) (2012).

200. Illustrating the odd nature of the three-judge district court, there are exceptions to what the court must decide. Once the three-judge district court has ruled on the merits of the claim, there may be collateral issues remaining, such as an award of attorneys' fees. Because the language of the convening statute arguably does not cover those topics, courts have typically held that the court's disposition of those issues is appealable in the first instance to the circuit court, not the Supreme Court. See, e.g., League of Women Voters of Mich. v. Johnson, 902 F.3d 572 (6th Cir. 2018) (appeal from three-judge district court of denial of motion to intervene under Federal Rule of Civil Procedure 24); Brat v. Personhuballah, 883 F.3d 475 (4th Cir. 2018) (appeal of award of attorneys' fees by three-judge district court); see also 17 Charles Alan Wright et Al., Federal Practice ANd Procedure § 4040, at 11415 (2007).

Another exception is when the district judge, to whom the case is originally assigned, decides that a three-judge district court should not be convened because the case does not satisfy the terms of the statute. The Supreme Court has never been clear on whether the appeal of such a decision should be directly to it, or first to the circuit court. See WRIGHT ET AL., supra, at 94-100 (noting that the Supreme Court or the court of appeals can order the lower court to convene a three-judge district court). Most courts allow an appeal to the circuit court and treat the case under its normal appellate procedure. For a recent example, see Benisek v. Mack, 584 F. App'x 140 (4th Cir. 2014), rev'd sub nom. Shapiro v. McManus, 136 S. Ct. 450 (2015).

Shapiro itself might be said to be less than clear on this point. In that case, the Court held that a district judge is required to convene a three-judge district court unless the claim is "insubstantial." 136 S. Ct. at 455. That language might suggest that circuit precedent would govern that issue, because an appeal of a dismissal on such grounds would go to the circuit, and presumably circuit precedent would govern that appeal. For two reasons, however, this interpretation misreads Shapiro. For one, the Supreme Court has long remained unclear on whether an appeal of such a decision by a single district judge must go to the circuit, or on direct appeal to the Court, or perhaps even be subject to writ of mandamus by the Court. See WRIGHT ET AL., supra, at 94-95 n.16 (discussing cases which allow for all three possibilities). For another, the discussion on insubstantiality in Shapiro is concerned with the jurisdiction of any federal court; if the claim is indeed insubstantial, then no federal court can hear the case. In contrast, Shapiro says that if the claim is not insubstantial-that is, so long as there is federal jurisdiction - then only a three-judge district court can dismiss it on the merits. $136 \mathrm{~S}$. Ct. at $455-56$. We do not read Shapiro as undermining our arguments: once there is federal jurisdiction, only a three-judge district court can render substantive rulings in the case, and those rulings are appealable only to the Supreme Court. We thank Michael Morley for his helpful comments on this point. 
follow only the precedent of a court "superior" to it, then only Supreme Court precedent binds a three-judge district court.

\section{PRUDENTIAL CONSIDERATIONS FOR DETERMINING THE PRECEDENTIAL WEIGHT OF CIRCUIT LAW ON THREE-JUDGE DISTRICT COURTS}

If the conclusion that circuit precedent should not bind three-judge district courts is so obvious, then why is it a distinctly minority position among the courts that have addressed the issue? We can think of several explanations: (1) a desire to achieve uniformity, (2) the perceived benefits from the percolation of issues, and (3) efficiency. ${ }^{201}$ Yet, upon further reflection, none of these justifications are convincing. Further, other exceptions to when one court must follow the law of another court even when the first court cannot overrule the second-such as the circuit court prior-panel rule_-are inapplicable in this setting.

First, consider uniformity, or the desire to have district courts within a circuit rule in the same way. The only method to ensure this occurs is to require all district courts, including three-judge district courts, to follow circuit precedent. If a three-judge district court is not obliged to follow circuit precedent, then similarly (though not identically) situated litigants living in the same state (never mind the same circuit) arguably could have their rights litigated under different legal regimes. Recall the decision in Parker $v$. Ohio, the case in which a three-judge district court invoked Sixth Circuit precedent to reject the plaintiffs' request for the creation of "influence districts" to avoid the dilution of African-American voting strength. ${ }^{202}$ Refusing to follow circuit precedent would have meant that the three-judge district court within the Sixth Circuit, and the Sixth Circuit itself, would have diverged on how to interpret this kind of claim under the Voting Rights Act.

But there are probably few cases in which a three-judge district court will find circuit precedent wrong. Those cases, however, involve the structure and functioning of our democracy, so although few in number, they are large in importance. By leaving the three-judge district court intact for reapportionment cases in 1976, Congress in effect designated those courts as specialized tribunals that could give greater attention to these particularly important cases. ${ }^{203}$ Requiring

201. In addition to the reasons we discuss in the text, there might be the more prosaic explanation of path dependence: most judges and lawyers may be comfortable with the majority rule and see no reason to argue to the contrary, to the extent they consider the issue at all. Thus, it is very common for threejudge district courts to cite and follow circuit precedent without even mentioning whether they believe circuit precedent binds them. See, e.g., Corman v. Torres, 287 F. Supp. 3d 558 (M.D. Pa. 2018) (threejudge court).

202. 263 F. Supp. 2d 1100, 1105 (S.D. Ohio 2003) (three-judge court) (relying on Cousin v. Sundquist, 145 F.3d 818, 828 (6th Cir. 1998)).

203. It is unclear why Congress left this exception in place when it abolished the rest of the jurisdiction of three-judge district courts. From the relatively scant legislative history on point, Congress apparently concluded that the perceived virtues of three-judge district courts, including multimember decisionmaking, arguably greater legitimacy, and prompt review when necessary by the Supreme Court, remained important for possibly high-profile and controversial reapportionment cases. See generally Douglas, supra note 16, at 462-63 (discussing the virtues and weaknesses of three-judge district courts); Mullen, supra note 184, at 376 (discussing some of the perceived problems of three-judge district courts 
uniformity with circuit case law would hamper the ability of three-judge district courts to decide these significant issues independently. A desire for uniformity should not outweigh the primary goal behind Congress's creation of three-judge district courts.

Encouraging percolation of issues might supply another reason to support a regime in which circuit precedent is binding on three-judge district courts. Often the Supreme Court will not grant certiorari in a case unless there is a circuit split and lower courts have considered various aspects of the issue. In this way, the issue can "percolate" among lower courts, which helps to inform the Supreme Court's analysis. ${ }^{204}$ But if three-judge district courts are free agents unbound by circuit precedent, then possibly novel legal issues will be decided at the trial level, with a direct appeal to the Supreme Court. The Court is then obliged to decide the case on the merits, unaided by the usual percolation of issues in circuit courts. ${ }^{205}$ Although it is not clear whether the Supreme Court's decisions are "better" after percolation of an issue, there is at least some evidence that lower court percolation aids the Court's review. ${ }^{206}$

But this concern overlooks the fact that percolation can occur among threejudge district courts for the topics that Congress deemed important enough for these specialized tribunals, including inherently political issues involving redistricting and campaign finance. Requiring three-judge district courts to follow circuit precedent would take away their ability to consider arguments independently, precluding the issues from percolating within the three-judge district courts that are actively reviewing them. Consider, for instance, the issue of whether and to what extent political gerrymandering claims are justiciable in federal court and, if so, the appropriate judicial standard to use. When the Supreme Court confronted that issue in Vieth $v$. Jubelirer, ${ }^{207}$ the Court drew on the experience of various three-judge district courts, citing several that had rejected claims of partisan gerrymandering under the then-prevalent standard to show that the standard was unworkable. $^{208}$ The most recent round of litigation on this point during the 2017

but noting they may be helpful to achieve actual or perceived fairness in reapportionment cases, which necessarily involve politics); Solimine, supra note 33, at 144-45 (discussing the perceived "importance" of three-judge district court cases and the three-judge district court's supposed ability to neutralize the effects of individual judges' partisanship). We acknowledge that the text and legislative history of the 1976 amendment does not directly address the precise issue discussed in this Part of the Article. But for the reasons discussed in the text, we think a reasonable inference from Congress's decision to leave the three-judge district court, and its direct appeal provision, intact for reapportionment cases supports the notion that circuit precedent does not formally bind those courts.

204. See Solimine, supra note 33, at 142-45 (discussing the impact of direct appeals from threejudge district courts on percolation).

205. Id.; cf. Nicholas O. Stephanopolous, The Relegation of Polarization, 83 U. CHI. L. REV. ONLINE 160,165 (2017) (arguing that "doctrinal confusion" has arisen in the development of reapportionment law in lower courts regarding section 2 of the Voting Rights Act given direct appeals and lack of intermediate appellate review).

206. See Solimine, supra note 31, at 146-47 (highlighting studies that suggest some benefits based on percolation in helping the Court decide which cases to take and in ultimately resolving a dispute).

207. 541 U.S. 267 (2004) (plurality opinion).

208. Id. at 279-81, 279-81 \& n.6. 
Term in Gill v. Whitford ${ }^{209}$ also stemmed from disparate resolutions of partisan gerrymandering claims among several three-judge district courts. ${ }^{210}$ Thus, percolation still can occur for these issues where it is most appropriate: among threejudge district courts themselves.

Finally, perhaps it is more efficient to follow the law with which the members of any three-judge district court are most familiar and consider controlling precedent, namely, the law of that circuit, especially given the presumed superiority of circuit court decisionmaking. Circuit law is potentially better reasoned because three judges, instead of one, sit on the panel to decide a case, allowing multiple minds to shape a decision. Yet the purported superiority of resolving difficult legal issues by multimember appellate courts is irrelevant here given that threejudge district courts are, by definition, multimember tribunals. They already benefit from the considered judgment of three federal judges regardless of whether they must follow circuit precedent or not. In addition, although it may be more efficient for three-judge district courts to have caselaw they must follow-because being forced to adhere to binding precedent might make the decisionmaking process easier and faster - that efficiency would come with a significant trade-off in independence and legitimacy. There is nothing to suggest that Congress wanted three-judge district courts to give up all of their independence in favor of efficiency. The specialized court itself already benefits from a faster resolution process by skipping the court of appeals stage, so there is no reason to favor efficiency over all other goals, including the desire to allow three judicial minds to come to their own decision on an important issue.

Separate from these prudential considerations, perhaps three-judge district courts must follow circuit precedent, even though circuit courts cannot review their decisions, as a corollary to the courts of appeals' prior-panel rule, a prominent exception to the notion that only higher court caselaw is binding. ${ }^{211}$ Under the prior-panel rule, a decision of a three-judge panel in a circuit court binds all future three-judge panels in that circuit; only the court sitting en banc (or the Supreme Court) may overrule a three-judge appellate panel's decision. ${ }^{212}$ The

\footnotetext{
209. 138 S. Ct. 1916 (2018).
}

210. See Whitford v. Gill, 218 F. Supp. 3d 837, 890 \& n. 176 (W.D. Wis. 2016) (citing Radogno v. Ill. State Bd. of Elections, No. 1:11-cv-04884, 2011 WL 5025251, at *4-6 (N.D. Ill. Oct. 21, 2011) (referring to other three-judge district court decisions from different circuits, handed down since Vieth, addressing political gerrymandering claims)), vacated on other grounds, 138 S. Ct. 1916 (2018).

211. There are other instances in which federal courts consider themselves bound by precedent generated by non-reviewing courts, such as following state law in diversity cases, or relatedly asking state courts certified questions of state law. Charles Alan Wright \& MARY Kay Kane, LaW OF FEDERAL COURTS 333-35, 390-97 (7th ed. 2011).

212. See, e.g., Cooper \& Berman, supra note 138, at $721 \mathrm{n} .91$ ("Panels in each circuit have consistently stated that they lack the authority to overrule decisions by prior panels; thus, as a general matter, a panel's decision binds subsequent panels absent an intervening decision of the Supreme Court, act of Congress, or en banc decision by the court as a whole."); Martha Dragich, Uniformity, Inferiority, and the Law of the Circuit Doctrine, 56 Loy. L. Rev. 535, 538 (2010); Phillip M. Kannan, The Precedential Force of Panel Law, 76 MARQ. L. REv. 755, 755-56 (1993) (noting that under the priorpanel rule, "[n]o panel can overrule the precedent established by any panel in the same circuit; all panels are bound by prior panel decisions in the same circuit"); Joseph W. Mead, Stare Decisis in the Inferior 
rule appears to rest on an assumption by the circuit courts that, because the en banc court is authorized to overrule prior precedent, individual panels are not. ${ }^{213}$ Permitting only en banc courts to overrule circuit precedent may improve judicial administration because it reduces the number of intra-circuit conflicts and thereby provides greater certainty for district courts. ${ }^{214}$ Thus, although not theorized deeply, the prior-panel rule seems to rest on concerns of uniformity and finality. ${ }^{215}$

But, for several reasons, the justifications underlying the prior-panel rule do not apply to three-judge district courts and do not justify application of a similar rule in this context. Uniformity and finality are not as pressing for three-judge district courts, at least as compared to other virtues such as impartiality and legitimacy, given the specific subject matters at issue. The whole point of having certain cases, which mostly involve politics at a broad level, go to three judges at the outset is to avoid the reality or perception of ideology affecting the decision at the trial level, as well as to increase the likelihood of reaching the "correct" result early in the process. ${ }^{216}$ If a three-judge district court must follow a prior appellate panel's decision, then that forced adherence might take away the perceived independence and corresponding greater legitimacy of the three-judge district court's decision. Because these cases are often viewed as inherently political, the threejudge district court should be unshackled from a prior decision that does not formally bind it. Three-judge district courts should have the independence to rule in the way they deem "correct," using the prior circuit law as highly persuasive but not formally binding. This is the best way to promote the ideals of unbiased and legitimate decisionmaking, which are particularly important virtues of the threejudge district court.

To be sure, the reverse is also possible: making three-judge district courts free agents could potentially increase ideologically-based decisionmaking, especially if prior circuit precedent, which the three-judge district court need not follow, is seen as unbiased. The judges on three-judge district courts could ignore circuit law to rule in a more explicitly ideological way. But they would have to do so while explaining their reasons for departing from that circuit precedent, which otherwise would be persuasive (though not mandatory). The requirement that judges explain their decisions would hopefully temper most judges' desire to ignore circuit precedent solely based on partisan motivation, as opposed to

Courts of the United States, 12 NEVADA L.J. 787, 794-95 (2012) (noting that all circuits, "with the arguable exception of the Seventh Circuit," follow a "law of the circuit" rule, while the Seventh Circuit allows one panel to overrule another but requires the court to circulate any such opinion to all active judges, who may then decide to take the case en banc).

213. See FED. R. APP. P. 35 (addressing en banc review); Kannan, supra note 212, at 756.

214. See Textile Mills Sec. Corp. v. Comm'r, 314 U.S. 326, 334-35 (1941) (noting that allowing circuit courts to sit en banc leads to "more effective judicial administration," the avoidance of intracircuit conflict, and the promotion of finality in the decisions of the circuit courts).

215. As Professor Hellman demonstrates, however, circuit courts occasionally create intra-circuit conflict despite the prior-panel rule. See Arthur D. Hellman, Precedent, Predictability, and Federal Appellate Structure, 60 U. PITT. L. REV. 1029, 1092-97 (1999).

216. See Douglas, supra note 16, at 462, 467. 
legitimate, jurisprudential reasoning. Of course, judges might analyze an issue to reach a desired outcome regardless of whether they are part of a three-judge district court. A requirement that they follow circuit precedent might temper outcome-determinative decisionmaking. There are thus competing interests on both sides.

Congress's goals should tip the balance: a major rationale behind the ThreeJudge Court Act is that three minds at the trial level are better than one for these political cases to achieve greater legitimacy and independence. ${ }^{217}$ Requiring three-judge district courts to follow circuit precedent blindly, when the circuit cannot review the decision, detracts from the independence and value otherwise afforded by a trial panel in which three judges, rather than one, deliberate to reach an outcome in a politically charged case; it quite literally would take away the benefit of three minds deliberating anew on the most appropriate rule. Congress has designated certain kinds of cases as unique because of their subject matter. The rules of decisionmaking for these special tribunals should promote the reasons behind their creation.

Additionally, binding three-judge district courts with prior circuit precedent does not assist in finality in the same way as the prior-panel rule. The prior-panel rule exists in large part to avoid intra-circuit conflict so that district judges in the circuit will know the "law of the circuit," thereby easing their decisionmaking process. A district judge will face certain reversal if he or she does not follow circuit precedent, at least by the three-judge panel that reviews the decision. Of course, a district court might note that it finds circuit precedent to be wrong, and it could call upon the en banc court to overrule that circuit law. But if the initial appellate panel is faithful to the prior-panel rule, it will necessarily reverse a district judge that rules contrary to prior circuit caselaw. This leads to greater efficiency for both the district court and the initial circuit court panel (not to mention the litigants). A three-judge district court, by contrast, will not face certain reversal if it refuses to follow circuit law because the circuit court will not hear an appeal of its decision. Further, we are aware of no cases in which the Supreme Court reversed a three-judge district court simply for the lower court's failure to follow circuit precedent. Thus, three-judge district courts do not need the finality of circuit law to operate efficiently.

\section{E. ONLY SUPREME COURT PRECEDENT BINDS THREE-JUDGE DISTRICT COURTS, BUT CIRCUIT LAW IS PERSUASIVE}

Having concluded, for both legal formalist reasons and prudential considerations alike, that circuit court precedent does not bind three-judge district courts, we turn to our final question: what precedent does bind three-judge district courts? Supreme Court precedent, of course, binds all lower federal courts, whether based on constitutional or prudential rationales. But what precedent should three-judge district courts follow in a situation in which there is no 
Supreme Court caselaw directly on point, but where other lower courts have addressed the issue? Such a situation presents the crux of the problem.

On the one hand, a three-judge district court, in this context, is essentially a free agent and should decide the case as it deems best in light of any persuasive authority from any source available. On the other hand, circuit precedentalthough not formally binding-is highly persuasive, and three-judge district courts should follow it unless special reasons counsel against doing so. ${ }^{218}$

Ultimately, three-judge district courts should not be required to follow circuit precedent, but they should consider carefully intra-court comity before they choose to depart from a prior ruling of the circuit court. A three-judge district court may validly disregard prior circuit law if there are "unusual or exceptional circumstances." 219 Such exceptional circumstances could include a fresh review of the age and persuasiveness of the precedent and any changes in the legal and social landscape since the circuit court ruled, including the presence or absence of subsequent circuit splits. ${ }^{220}$ Specific considerations relevant to reapportionment or campaign finance cases may also provide justification for refusing to follow circuit law.

The practical effect of allowing three-judge district courts to depart from circuit precedent could be small. Many three-judge district courts will find circuit law highly persuasive and will choose to follow it even if they are not formally bound. But this shift in approach changes the kinds of arguments the litigants will make, as well as the judicial inquiry required of judges. Litigants would have the full suite of caselaw from across the country with which to make their arguments, which would be particularly helpful if there is unfavorable caselaw from their own circuit. Plaintiffs in voting rights cases, for example, might attempt novel

218. Here and elsewhere we are primarily referring to substantive law issues, possibly subject to differing interpretations in different circuits. In contrast, we can imagine that the circuits might follow different standards on procedural issues such as evidentiary privileges or burdens of proof. As in other contexts, the line between the two may not always be clear, but there would be strong reasons of convenience and efficiency for a three-judge district court to follow the local circuit's procedural rules, not directly related to the reapportionment, Voting Rights Act, or campaign finance issues that form the merits of the case. In any event, whether an issue is procedural or substantive, a three-judge district court should not consider circuit precedent to be formally binding.

219. Cf. Kannan, supra note 212, at 755 n.6 (citing United States v. Anaya, 509 F. Supp. 289, 923 (S.D. Fla. 1980) (noting that district courts follow this rule for prior district court decisions)).

220. See, e.g., Texas v. United States, 887 F. Supp. 2d 133, 174-75 (D.D.C. 2012) (three-judge court) (canvassing views of different circuits in a preclearance action under section 5 of the Voting Rights Act and then following the majority view), vacated on other grounds, 570 U.S. 928 (2013).

An interesting and related question is whether, under our proposal, three-judge district courts should presumptively follow the decisions of other three-judge district courts. In theory, this would build up a body of law entirely separate from circuit law. We think that this development, as a formal matter, is unnecessary. For one, a three-judge district court cannot overrule a prior three-judge district court's opinion; the courts are, by their very nature, sui generis. In addition, any prior decisions-by any court-on the same exact issue will always be persuasive to a subsequent court. But new legal developments or nuances in the facts could counsel a different result for a multimember tribunal sitting as a trial court, much in the same way that occurs with single district court judges all the time. A threejudge district court should therefore treat a prior three-judge district court ruling in the same way that a single district judge considers a prior single district judge's decision. 
arguments that a court in another part of the country has accepted, which can help the evolution of the substantive doctrine. Moreover, the three-judge district court will have to scrutinize more carefully the validity of prior rulings on the issue, which will give these courts greater independence, likely resulting in better decisionmaking and potentially increasing confidence in the courts' legitimacy. This independence might also lead three-judge district courts to reach different outcomes in certain cases. More importantly, adopting this approach will unshackle three-judge district courts from the rigid rule that they must follow circuit precedent, allowing three judicial minds to consider the question from a fresh perspective, which is exactly what Congress expected when creating these specialized courts.

In sum, prior circuit court decisions may be highly persuasive, but they are not and should not be formally binding. Requiring three-judge district courts to follow circuit precedent could undermine their perceived independence and legitimacy. No congressional or court rule requires these courts to follow circuit precedent. In fact, formal and prudential considerations point in the opposite direction. When faced with circuit law, the three-judge district court should consider it carefully, but if it finds the prior caselaw unpersuasive, no formal rule or normative consideration requires unblinking adherence.

\section{CONCLUSION}

Both questions we have discussed in this Article-whether the Supreme Court's summary affirmances of three-judge district courts are fully precedential and whether three-judge district courts must follow circuit precedent-significantly impact the underlying substantive rights involved in these cases. Three-judge district courts decide disputes that involve the core concepts of our democracy, including democratic representation and campaign finance. Thus, how these courts operate plays a vital role in the very functioning of our democracy.

The solutions we have proposed will give judges more flexibility in deciding these cases. The federal judiciary should serve as a backstop to overarching partisanship in election rules. ${ }^{221}$ The Supreme Court's practice with respect to summary affirmances is confusing and makes it hard for three-judge district courts to know which precedents actually bind them. In addition, the majority view that circuit precedent binds three-judge district courts hampers those courts' ability to serve the primary role inherent in their creation: to provide greater deliberation and independent judgment through three judges at the outset of a case involving one of these core democratic topics. Assuming that Congress retains these specialized courts, then the reforms we have proposed will streamline their procedure and ultimately will make their substantive decisionmaking stronger, which will augment the judiciary's ability to ensure a fair election process. ${ }^{222}$

221. See Richard L. Hasen, The 2012 Voting Wars, Judicial Backstops, and the Resurrection of Bush v. Gore, 81 GEO. WASH. L. REv. 1865, 1868 (2013).

222. The Court could also request that Congress repeal the direct appeal statute and either (1) replace it with certiorari-like procedures, or (2) repeal the reapportionment exception entirely. The latter move 
We are simply calling for precedential rules in the three-judge district court context that make sense for judicial hierarchy and economy. The current practices are probably not a product of reasoned thought or deliberation but are more likely ad hoc methods to dispose of these cases. Close examination of these practices reveals how both the Supreme Court and three-judge district courts are off track. Reforming the precedential rules for three-judge district courts will go a long way toward ensuring that such courts perform the vital role that Congress intended in resolving the most difficult, political cases that the federal judiciary encounters.

would leave intact three-judge district courts found in specific statutes, though those can be repealed as well. The Supreme Court was not shy about lobbying Congress to change the three-judge district court statute in the 1970s, see supra notes 38-40 and accompanying text, and it could do so again. Whether Congress would listen, however, is an entirely different matter. This is why our proposal takes the threejudge district court as a given, assuming that it will endure for the time being, and attempts to find ways to make it a more workable and coherent procedure for both litigants and the judicial system as a whole. 